\title{
Blue Radiation Interacts with Green Radiation to Influence Growth and Predominantly Controls Quality Attributes of Lettuce
}

\author{
Qingwu Meng \\ Department of Horticulture, Michigan State University, 1066 Bogue Street, East Lansing, MI 48824 \\ Jennifer Boldt \\ USDA-ARS, Greenhouse Production Research Group, 2801 West Bancroft Street, Mail Stop 604, \\ Toledo, $\mathrm{OH} 43606$ \\ Erik S. Runkle \\ Department of Horticulture, Michigan State University, 1066 Bogue Street, East Lansing, MI 48824
}

Additional Index words. essential nutrients, indoor farming, light-emitting diode, morphology, red radiation, sensory quality

\begin{abstract}
Adding green [G (500-600 nm)] radiation to blue [B (400-500 nm)] and red [R (600-700 nm)] radiation creates white radiation and improves crop inspection at indoor farms. Although $G$ radiation can drive photosynthesis and elicit the shade-avoidance response, its effects on plant growth and morphology have been inconsistent. We postulated $G$ radiation would counter the suppression of crop growth and promotion of secondary metabolism by $B$ radiation depending on the B photon flux density (PFD). Lettuce (Lactuca sativa 'Rouxai') was grown in a growth room under nine sole-source light-emitting diode (LED) treatments with a 20-hour photoperiod or in a greenhouse. At the same photosynthetic photon flux density $[P P F D(400-700 \mathrm{~nm})]$ of $180 \mu \mathrm{mol} \cdot \mathrm{m}^{-2} \cdot \mathrm{s}^{-1}$, plants were grown under warm-white LEDs or increasing $B P F D s$ at $0,20,60$, and $100 \mu \mathrm{mol} \cdot \mathrm{m}^{-2} \cdot \mathrm{s}^{-1}$ with or without substituting the remaining $R$ radiation with $60 \mu \mathrm{mol} \cdot \mathrm{m}^{-2} \cdot \mathrm{s}^{-1}$ of $G$ radiation. Biomass and leaf expansion were negatively correlated with the $B P F D$ with or without $G$ radiation. For example, increasing the $B P F D$ decreased fresh and dry mass by up to $63 \%$ and $54 \%$, respectively. The inclusion of $G$ radiation did not affect shoot dry mass at 0 or $20 \mu \mathrm{mol} \cdot \mathrm{m}^{-2} \cdot \mathrm{s}^{-1} \mathrm{of} \mathrm{B}$ radiation, but it decreased it at 60 or $100 \mu \mathrm{mol} \cdot \mathrm{m}^{-2} \cdot \mathrm{s}^{-1}$ of $B$ radiation. Results suggest that the shade-avoidance response is strongly elicited by low $B$ radiation and repressed by high $B$ radiation, rendering $G$ radiation ineffective at controlling morphology. Moreover, substituting $R$ radiation with $G$ radiation likely reduced the quantum yield. Otherwise, $G$ radiation barely influenced morphology, foliage coloration, essential nutrients, or sensory attributes regardless of the $B$ PFD. Increasing the $B$ PFD increased red foliage coloration and the concentrations of several macronutrients (e.g., nitrogen and magnesium) and micronutrients (e.g., zinc and copper). Consumers preferred plants grown under sole-source lighting over those grown in the greenhouse, which were more bitter and less acceptable, flavorful, and sweet. We concluded that lettuce phenotypes are primarily controlled by $B$ radiation and that $G$ radiation maintains or suppresses lettuce growth depending on the B PFD.
\end{abstract}

Because of the emerging interest in producing local, fresh, and nutritious food throughout the year, indoor farming has recently been expanding rapidly in urban and peri-urban areas (Kozai et al., 2015). High-value, fast-growing, and short-stature crops, such as leafy greens and herbs, are common crop types that are suitable for commercial indoor vertical farming (Kozai et al., 2015). Light-emitting diodes (LEDs) are the predominant

Received for publication 6 June 2019. Accepted for publication 17 Sept. 2019. Published online 10 January 2020.

We thank David Hamby, Rodrigo Pereyra, Charles Brunault, Alan Sarkisian, and Dorian Spero from OSRAM Innovation for lighting support; Nathan Kelly for experimental assistance; Steve Brooks for technical assistance; Sungeun Cho, Edward Szczygiel, and Shelby Cieslinski from Michigan State University Department of Food Science and Human Nutrition for help with consumer preference tests; Douglas Sturtz and Mona-Lisa Banks from USDA-ARS for help with elemental analysis; Randy Beaudry, Dan Brainard, Roberto Lopez, and Emily Merewitz for instruments; and material donations from Grodan and JR Peters, Inc. This work was supported by Michigan State University AgBioResearch (including Project GREEEN GR17-072) and the USDA National Institute of Food and Agriculture (Hatch project 192266).

E.S.R. is the corresponding author. E-mail: runkleer@msu.edu.

This is an open access article distributed under the CC BY-NC-ND license (https://creativecommons.org/licenses/by-nc-nd/4.0/). light source of indoor vertical production systems because they can be placed close to the crop canopy, are energyefficient and long-lasting, and have customizable spectral distributions (Massa et al., 2008). Because radiation quality influences physiological processes such as photosynthesis, photomorphogenesis, and secondary metabolism, characterizing and understanding crop spectral responses are crucial to achieving desired yield and quality attributes, such as shape, texture, nutritional value, and organoleptic properties. Biologically relevant wavebands delivered by LEDs include ultraviolet (280-400 nm), blue [B (typical peak wavelength, $450 \mathrm{~nm}$ )], green [G (typical peak wavelength, $525 \mathrm{~nm}$ )], red [R (typical peak wavelength, $660 \mathrm{~nm}$ )], and far red [FR (700-800 $\mathrm{nm}$; typical peak wavelength, $735 \mathrm{~nm}$ )]. Changing the spectral composition can shift the energy balance to affect quantum efficiency and photoprotective mechanisms involving secondary metabolic compounds (Hogewoning et al., 2012; Kopsell et al., 2015). However, the spectral composition, such as the ratio of $\mathrm{R}$ to $\mathrm{FR}$ radiation, can evoke the shade-avoidance response to modify morphological traits (Franklin, 2008). 
A typical green leaf of plants grown in growth chambers absorbed $\approx 92 \%$ of $B$ radiation $(450 \mathrm{~nm}), 92 \%$ of $\mathrm{R}$ radiation $(660 \mathrm{~nm})$, and $81 \%$ of $\mathrm{G}$ radiation $(525 \mathrm{~nm})$ (McCree, 1972). Radiation transmission and reflection are higher for $\mathrm{G}$ radiation than for B or R radiation. Although chlorophylls $a$ and $b$ on the adaxial leaf surface absorb most $B$ and $R$ radiation and little $G$ radiation, up to $80 \%$ of $\mathrm{G}$ radiation is transmitted through the mesophyll and penetrates deeper in the leaf profile (Brodersen and Vogelmann, 2010; Terashima et al., 2009). For a wide range of grain, oilseed, vegetable, and other crops grown in growth chambers, the relative quantum yields based on absorbed photons in low light $\left(\approx 100 \mu \mathrm{mol} \cdot \mathrm{m}^{-2} \cdot \mathrm{s}^{-1}\right)$ were $\approx 0.75,0.74$, and 0.93 for $\mathrm{B}(450 \mathrm{~nm}), \mathrm{G}(525 \mathrm{~nm})$, and $\mathrm{R}$ radiation $(660 \mathrm{~nm})$, respectively (McCree, 1972; Sager et al., 1988). More recently, quantum yields at various wavelengths were quantified again for cucumber [Cucumis sativus (Hogewoning et al., 2012)]. In low light, the quantum yield based on absorbed photons was highest for $\mathrm{R}$ radiation, followed by $\mathrm{G}$ radiation and then $\mathrm{B}$ radiation, whereas the quantum yield based on incident photons was the highest for $\mathrm{R}$ radiation and similarly lower for $\mathrm{B}$ and $\mathrm{G}$ radiation $[\approx 70 \%$ of the highest yield (Hogewoning et al., 2012)]. The quantum yield under absorbed $G$ radiation was higher than that under $B$ radiation because of the deeper penetration of $G$ radiation in the mesophyll and its prolonged light paths in the leaf through scattering (Smith et al., 2017). Therefore, $\mathrm{G}$ radiation drives photosynthesis effectively despite its relatively weak absorption by chlorophylls and widely misconceived low quantum efficiency. The spectral composition in the background and spectra need to be clearly defined when evaluating the effects of additional $\mathrm{G}$ radiation on photosynthesis. For example, in theory, substituting incident B radiation with $\mathrm{G}$ radiation would not change the quantum yield, whereas substituting incident $R$ radiation with $G$ radiation would decrease it.

A low ratio of $R$ to $F R$ radiation, low $B$ radiation, and inclusion of $G$ radiation can trigger the shade-avoidance response, such as promotion of extension growth, acceleration of flowering, and hyponasty (Keuskamp et al., 2011; Smith and Whitelam, 1997; Zhang et al., 2011). The shade-avoidance response is mediated by phytochromes, such as phytochrome B, at a low ratio of $\mathrm{R}$ to $\mathrm{FR}$ radiation, by cryptochromes 1 and 2 in low $\mathrm{B}$ radiation, and through a less understood mechanism in the presence of G radiation (Pedmale et al., 2016; Smith and Whitelam, 1997; Zhang et al., 2011). Increased leaf expansion under shade signals such as a low ratio of $\mathrm{R}$ to $\mathrm{FR}$ radiation can increase radiation capture, thereby promoting whole-plant photosynthesis (Park and Runkle, 2017). Many shade-induced genes upregulated by FR radiation can also be activated by $G$ radiation, although suppression of gene expression by cryptochromes in $\mathrm{G}$ radiation occurs without FR radiation (Zhang et al., 2011). At the whole-plant level, at a photosynthetic photon flux density $(P P F D)$ of $150 \mu \mathrm{mol} \cdot \mathrm{m}^{-2} \cdot \mathrm{s}^{-1}$, substituting $36 \mu \mathrm{mol} \cdot \mathrm{m}^{-2} \cdot \mathrm{s}^{-1}$ of $\mathrm{R}$ radiation with $\mathrm{G}$ radiation at a $\mathrm{B}$ photon flux density $(P F D)$ of 23-24 $\mu \mathrm{mol} \cdot \mathrm{m}^{-2} \cdot \mathrm{s}^{-1}$ promoted leaf expansion and biomass accumulation of 'Waldmann's Green' lettuce (Kim et al., 2004). However, other studies suggested minimal roles of $\mathrm{G}$ radiation in plant growth and morphology. For example, at a PPFD of $150 \mu \mathrm{mol} \cdot \mathrm{m}^{-2} \cdot \mathrm{s}^{-1}$, substituting $\mathrm{R}$ in $\mathrm{B}+\mathrm{R}$ radiation with $15 \mu \mathrm{mol} \cdot \mathrm{m}^{-2} \cdot \mathrm{s}^{-1}$ of $\mathrm{G}$ radiation generally did not influence leaf shape or biomass of 'Green Skirt' lettuce when the B PFD was 0, 15,30 , or $45 \mu \mathrm{mol} \cdot \mathrm{m}^{-2} \cdot \mathrm{s}^{-1}$ (Kang et al., 2016). In addition, at a low $\mathrm{B}$ fraction of $10 \%$ to $14 \%$, increasing the $\mathrm{G}$ radiation fraction from
$0 \%$ to $41 \%$ did not influence the shoot dry mass of 'Waldmann's Green' lettuce at a PPFD of 200 or $500 \mu \mathrm{mol} \cdot \mathrm{m}^{-2} \cdot \mathrm{s}^{-1}$; however, it decreased its leaf area index by $11 \%$ at a $P P F D$ of $200 \mu \mathrm{mol} \cdot \mathrm{m}^{-2} \cdot \mathrm{s}^{-1}$, but not $500 \mu \mathrm{mol} \cdot \mathrm{m}^{-2} \cdot \mathrm{s}^{-1}$ (Snowden et al., 2016). These inconsistent findings regarding $G$ radiation necessitate a detailed investigation that eliminates possible confounding factors to elucidate spectral interactions.

Energetic B photons can elicit the accumulation of essential nutrients and secondary metabolites that have nutritional value and impart flavor (Kopsell et al., 2015; Son and Oh, 2013). For example, increasing the B PFD (or fraction) increased concentrations of total phenolics and flavonoids and promoted the antioxidant capacity of 'Sunmang' lettuce and 'Grand Rapids TBR' lettuce (Son and Oh, 2013). Partial substitution of white radiation with $\mathrm{B}$ radiation increased concentrations of anthocyanins, xanthophylls, and $\beta$-carotenes of 'Red Cross' lettuce (Li and Kubota, 2009). Increases in anthocyanins by high B radiation can be attributed to the increased activity of phenylalanine ammonia-lyase, a key enzyme in the biosynthetic pathways of polyphenol compounds (Heo et al., 2012). Because secondary metabolites such as phenolic compounds are bitter (Tomás-Barberán and Espín, 2001), B radiation can potentially affect consumer preferences of organoleptic properties. However, few studies of LED lighting have investigated spectral regulation of crop flavor and texture. In one study, compared with $\mathrm{B}+\mathrm{R}$ radiation, $\mathrm{B}+\mathrm{R}+$ white radiation and white fluorescent light improved sensory attributes, such as shape, color, sweetness, and crisp texture, of 'Capitata' lettuce, suggesting the influence of $\mathrm{G}$ radiation (Lin et al., 2013).

In a previous study, substituting $60 \mu \mathrm{mol} \cdot \mathrm{m}^{-2} \cdot \mathrm{s}^{-1}$ of $\mathrm{B}$ radiation with $\mathrm{G}$ radiation in a background of $120 \mu \mathrm{mol} \cdot \mathrm{m}^{-2} \cdot \mathrm{s}^{-1}$ of $\mathrm{R}$ radiation increased biomass accumulation and extension growth of 'Rex' lettuce, 'Rouxai' lettuce, and kale (Brassica oleracea var. sabellica 'Siberian') (Meng et al., 2019). However, because the B PFD decreased with incremental additions of $\mathrm{G}$ radiation, the promotion of plant growth under enriched $G$ radiation could also be attributed to reduced $B$ radiation. In the present study, to decouple the effects of $G$ radiation from those of $B$ radiation, $R$ radiation was partially substituted with $G$ radiation at various $B$ PFDs in the present study. In addition, indoor vertical farms and greenhouses are two major systems for producing crops in controlled environments, but few studies have compared their crop yield and quality. Therefore, we compared lettuce growth and quality in a growth room under sole-source lighting and in a greenhouse environment under sunlight with supplemental lighting. For 'Rouxai' red leaf lettuce, we postulated that 1) increasing the $\mathrm{B} P F D$, with or without $\mathrm{G}$ radiation, would decrease leaf expansion and biomass, increase the accumulation of anthocyanins, macronutrients, and micronutrients, and intensify the bitter taste; 2) partial substitution of $\mathrm{R}$ radiation with $\mathrm{G}$ radiation would counter the effects of $\mathrm{B}$ radiation in a $\mathrm{B} P F D$-dependent manner and elicit the shade-avoidance response, thereby increasing radiation interception and biomass; and 3) plant growth under sole-source lighting with low B radiation would be greater than that in a greenhouse environment with moderate $\mathrm{B}$ radiation from sunlight because increasing B radiation would reduce vegetative growth.

\section{Materials and Methods}

Plant material and propagation. This study was conducted in the Controlled-Environment Lighting Laboratory at 
Michigan State University (East Lansing). Seeds of 'Rouxai' red oakleaf lettuce were obtained from a seed producer (Johnny's Selected Seeds, Winslow, ME) and sown in a rockwool substrate sheet composed of 2002.5 -cm-wide square plugs (AO 25/40 Starter Plugs; Grodan, Milton, ON, Canada) on 11 Jan. and 19 Feb. 2018 for two replications. The substrate was held in a plastic tray and presoaked in deionized water with an adjusted pH of 4.3 using diluted (1:31) $95 \%$ to $98 \%$ sulfuric acid (J.Y. Baker, Phillipsburg, NJ). During the first $24 \mathrm{~h}$, seed trays were covered with transparent humidity domes and placed in a growth room at $20{ }^{\circ} \mathrm{C}$ under continuous lighting from warm-white LEDs (2700 K, PHYTOFY RL; Osram, Beverley, MA) at a total photon flux density [TPFD (400-800 nm)] of 50 $\mu \mathrm{mol} \cdot \mathrm{m}^{-2} \cdot \mathrm{s}^{-1}$. On day 1 , the air temperature, photoperiod, and TPFD were changed to $22{ }^{\circ} \mathrm{C}, 20 \mathrm{~h}$, and $180 \mu \mathrm{mol} \cdot \mathrm{m}^{-2} \cdot \mathrm{s}^{-1}$, respectively. The substrate was subirrigated with a nutrient solution [ $\mathrm{pH}, 5.7-5.9$; electrical conductivity (EC), 1.2-1.4 $\mathrm{mS} \cdot \mathrm{cm}^{-1}$ ] to supply the following nutrients (in $\mathrm{mg} \cdot \mathrm{L}^{-1}$ ): $125 \mathrm{~N}$, $18 \mathrm{P}, 139 \mathrm{~K}, 73 \mathrm{Ca}, 49 \mathrm{Mg}, 39 \mathrm{~S}, 1.7 \mathrm{Fe}, 0.52 \mathrm{Mn}, 0.56 \mathrm{Zn}, 0.13$ $\mathrm{B}, 0.47 \mathrm{Cu}$, and $0.13 \mathrm{Mo}$. The nutrient solution used from days 1 to 13 was made by supplementing deionized water with $12 \mathrm{~N}-$ 1.7P-13.3K water-soluble fertilizer (RO Hydro FeED; JR Peters, Allentown, PA) and magnesium sulfate (Epsom salt; Pennington Seed, Madison, GA). The $\mathrm{pH}$ was adjusted to the desired range by the addition of potassium bicarbonate and/or diluted sulfuric acid.

Lighting TREATMENTS. On day 4, after humidity domes were removed, 35 lettuce seedlings were transferred from warmwhite radiation to each of nine light-quality treatments at the same TPFD of $180 \mu \mathrm{mol} \cdot \mathrm{m}^{-2} \cdot \mathrm{s}^{-1}$ under a 20 -h photoperiod. Plants were exposed to four $\mathrm{B} P F D \mathrm{~s}$ in an $\mathrm{R}$ background without $\mathrm{G}$ radiation $\left(\mathrm{R}_{180}, \mathrm{~B}_{20} \mathrm{R}_{160}, \mathrm{~B}_{60} \mathrm{R}_{120}\right.$, and $\left.\mathrm{B}_{100} \mathrm{R}_{80}\right)$ or with the substitution of $G$ radiation for $R$ radiation $\left(G_{60} R_{120}\right.$, $\mathrm{B}_{20} \mathrm{G}_{60} \mathrm{R}_{100}, \mathrm{~B}_{60} \mathrm{G}_{60} \mathrm{R}_{60}$, and $\mathrm{B}_{100} \mathrm{G}_{60} \mathrm{R}_{20}$ ). The number following each waveband is its $P F D$ in $\mu \mathrm{mol} \cdot \mathrm{m}^{-2} \cdot \mathrm{s}^{-1}$. Additional plants were kept under warm-white radiation. The peak wavelengths of B, G, R, and warm-white LEDs included in each LED fixture (PHYTOFY RL; Osram) were 449, 526, 664, and $639 \mathrm{~nm}$, respectively. The LED hardware was paired with software (PHYTOFY Control Software; Osram) to create the lighting treatments and schedules. Each lighting treatment was delivered with an array of three identical LED fixtures $(67.3 \times$ $29.8 \times 4.3 \mathrm{~cm}$ each, placed $41 \mathrm{~cm}$ apart), and their color channels were controlled to deliver the desired spectral distributions. Before the onset of each replication, spectra were measured with a portable spectroradiometer (PS200; Apogee Instruments, Logan, UT) at the plant canopy (46 cm below the LED fixtures) and averaged from seven locations for each lighting treatment to create an average spectral distribution (Fig. 1). Single-band $P F D$ s for B, G, R, and FR radiation, integrated $P F D$ s (e.g., $T P F D$ and $P P F D$ ), and radiation ratios were calculated based on the average spectral distribution (Table 1). The yield photon flux density [YPFD (300$800 \mathrm{~nm})$ ] was the product of the spectral distribution and relative quantum yield according to Sager et al. (1988). The phytochrome photoequilibrium describes the fraction of FRabsorbing phytochromes in the total phytochrome pool and was estimated based on the spectral distribution and phytochrome absorption coefficients (Sager et al., 1988). The color rendering index, which measures how well a light source reveals object colors compared with a natural light source, was calculated with the online LED ColorCalculator (Osram Sylvania Inc., 2019).
The photosynthetic daily light integral [DLI (400-700 nm)] was $13.0 \mathrm{~mol} \cdot \mathrm{m}^{-2} \cdot \mathrm{d}^{-1}$.

Production culture and environment. On day 13, lettuce seedlings were transplanted to a deep-flow technique hydroponic system on three-layer growing racks (Indoor Harvest, Houston, TX) in the same radiation and temperature environment as before. Plants were positioned on 36-cell floating rafts $[60.9 \times 121.9 \times 2.5 \mathrm{~cm}$ (Beaver Plastics, Acheson, AB, Canada) $]$ in flood tables $[1.22 \times 0.61 \times 0.18 \mathrm{~m}$ (Active Aqua AAHR24W; Hydrofarm, Petaluma, CA)]. A nutrient solution was constantly recirculated by a water pump in a reservoir and oxygenated by an air stone $[20.3 \times 2.5 \mathrm{~cm}$ (Active Aqua AS8RD; Hydrofarm)] connected to an air pump (Active Aqua AAPA70L; Hydrofarm). It was made of deionized water supplemented with $12 \mathrm{~N}-1.7 \mathrm{P}-13.3 \mathrm{~K}$ water-soluble fertilizer (RO Hydro FeED) and potassium bicarbonate to supply the following nutrients (in $\mathrm{mg} \cdot \mathrm{L}^{-1}$ ): $150 \mathrm{~N}, 22 \mathrm{P}, 166 \mathrm{~K}, 88 \mathrm{Ca}, 58$ $\mathrm{Mg}, 47 \mathrm{~S}, 2.1 \mathrm{Fe}, 0.63 \mathrm{Mn}, 0.68 \mathrm{Zn}, 0.15 \mathrm{~B}, 0.56 \mathrm{Cu}$, and 0.15 Mo. The $\mathrm{pH}, \mathrm{EC}$, and water temperature for each rack housing three lighting treatments were measured daily with a $\mathrm{pH}$ and $\mathrm{EC}$ meter (HI9814; Hanna Instruments, Woonsocket, RI). The pH, $\mathrm{EC}$, and water temperature of nutrient solutions for nine solesource lighting treatments were (mean $\pm \mathrm{SD}$ ) $5.9 \pm 0.5$ to $5.9 \pm$ $0.7,1.76 \pm 0.12$ to $1.80 \pm 0.16 \mathrm{mS} \cdot \mathrm{cm}^{-1}$, and $23.1 \pm 0.3$ to $24.0 \pm$ $0.7^{\circ} \mathrm{C}$ in replication 1 , and $5.5 \pm 0.5$ to $5.8 \pm 0.7,1.77 \pm 0.10$ to $1.83 \pm 0.08 \mathrm{mS} \cdot \mathrm{cm}^{-1}$, and $23.1 \pm 0.2$ to $23.9 \pm 0.2{ }^{\circ} \mathrm{C}$ in replication 2 . When $\mathrm{pH}$ decreased to $<5.1$, it was increased to 5.6-5.9 using potassium bicarbonate. The nutrient solution tank was replenished with deionized water before the water pump surfaced. No additional fertilizers were added throughout the experiment. The $P P F D$, air temperature, $\mathrm{CO}_{2}$ concentration, and relative humidity were monitored with sensors and recorded as described by Meng et al. (2019). The mean air temperature, $\mathrm{CO}_{2}$ concentration, and relative humidity in the growth room were (mean $\pm \mathrm{SD}$ ) $22.4 \pm 0.6^{\circ} \mathrm{C}, 410 \pm 50 \mu \mathrm{mol} \cdot \mathrm{mol}^{-1}$, and $34 \% \pm 10 \%$, respectively, in replication 1 and $22.5 \pm 0.6^{\circ} \mathrm{C}, 398 \pm$ $35 \mu \mathrm{mol} \cdot \mathrm{mol}^{-1}$, and $35 \% \pm 7 \%$, respectively, in replication 2 .

Additional lettuce seedlings grown under warm-white radiation were transferred on day 13 to a glass-glazed greenhouse at $22{ }^{\circ} \mathrm{C}$ with an environmental control system (Integro 725; Priva, De Lier, The Netherlands). During a 16-h photoperiod (different from $20 \mathrm{~h}$ indoors to achieve comparable DLIs), supplemental lighting from high-pressure sodium lamps (PL2000; P.L. Light Systems, Beamsville, ON, Canada) was automatically switched on to provide an additional $P P F D$ of 60-90 $\mu \mathrm{mol} \cdot \mathrm{m}^{-2} \cdot \mathrm{s}^{-1}$ at plant height when the ambient $P P F D$ was $<185 \mu \mathrm{mol} \cdot \mathrm{m}^{-2} \cdot \mathrm{s}^{-1}$ and switched off when it was $>370$ $\mu \mathrm{mol} \cdot \mathrm{m}^{-2} \cdot \mathrm{s}^{-1}$. Supplemental lighting was manually turned off on day 23 in replication 2 because of an overabundance of sunlight. Supplemental lighting contributed $\approx 22 \%$ and $13 \%$ of the DLIs during replications 1 and 2, respectively. Plants were transplanted to $10-\mathrm{cm}$ plastic pots filled with a peat-perlite medium (Suremix; Michigan Grower Products, Galesburg, MI) and irrigated using an overhead watering can filled with reverse-osmosis water supplemented with the same $12 \mathrm{~N}-$ 1.7P-13.3K fertilizer (RO Hydro FeED) at the same nutrient concentrations as that for plants in the growth room. The initial $\mathrm{pH}$ and $\mathrm{EC}$ of the nutrient solution were 5.6 and $1.6 \mathrm{mS} \cdot \mathrm{cm}^{-1}$, respectively. The $\mathrm{pH}$ was maintained at $\approx 5.6$ using potassium bicarbonate throughout the experiment. An IR thermocouple (OS36-01-K-80F; Omega Engineering, Stamford, CT) and a line quantum sensor (Apogee Instruments) were used to mea- 

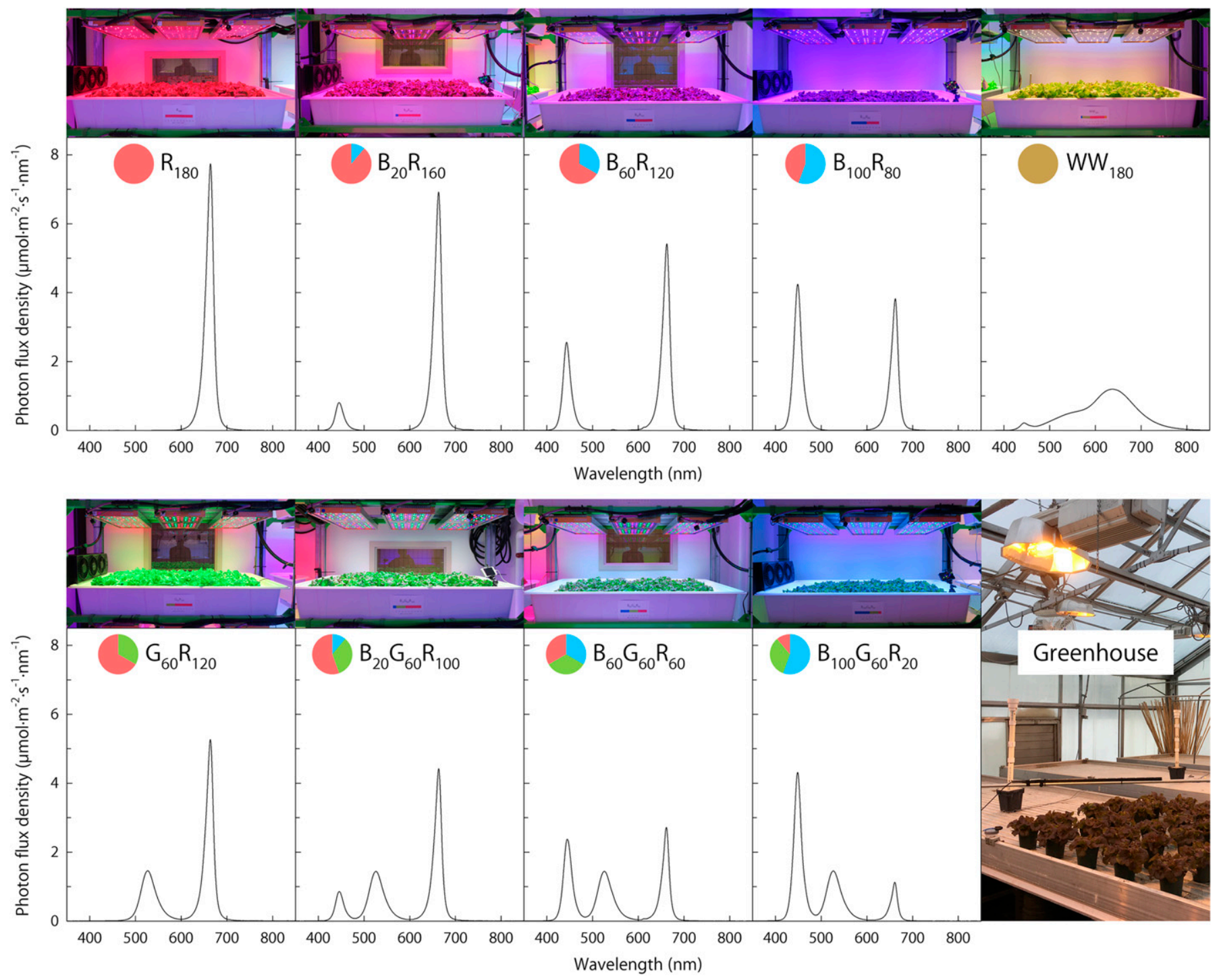

Fig. 1. Spectral distributions of nine sole-source lighting treatments delivered by mixtures of blue [B (400-500 nm)], green [G (500-600 nm)], and red [R (600-700 $\mathrm{nm}$ )], or warm-white (WW) light-emitting diodes. The greenhouse treatment received sunlight with supplemental high-pressure sodium lighting. The number following each waveband is its photon flux density in $\mu \mathrm{mol} \cdot \mathrm{m}^{-2} \cdot \mathrm{s}^{-1}$.

sure leaf temperature and the $P P F D$, respectively, at plant height. Hourly average data were calculated from instantaneous measurements every $10 \mathrm{~s}$ with a data logger (CR10; Campbell Scientific, Logan, UT). The mean leaf temperature and DLI were (mean $\pm \mathrm{SD}) 21.8 \pm 2.3{ }^{\circ} \mathrm{C}$ and $15.9 \pm 3.4 \mathrm{~mol} \cdot \mathrm{m}^{-2} \cdot \mathrm{d}^{-1}$, respectively, in replication 1 and $22.7 \pm 2.2^{\circ} \mathrm{C}$ and $19.2 \pm 4.9$ $\mathrm{mol} \cdot \mathrm{m}^{-2} \cdot \mathrm{d}^{-1}$, respectively, in replication 2 .

Data collection and analysis. On day 33 in replication 1 and day 30 in replication 2, growth data were collected from eight plants per treatment for destructive measurements. The harvest times of two replications were different by $3 \mathrm{~d}$ to accommodate subsequent prescheduled sensory tests. Shoot fresh and dry mass following $\geq 5 \mathrm{~d}$ in a drying oven (Blue $\mathrm{M}$, Blue Island, IL) at $60{ }^{\circ} \mathrm{C}$ were measured with an analytical balance (GX-1000; A\&D Store, Wood Dale, IL). Plant diameter (the longest horizontal distance between leaf peripheries), leaf length and width of the sixth true leaf, and leaf number (when $>3 \mathrm{~cm}$ ) were measured with a ruler. Relative specific chlorophyll content (SPAD index) was measured with a chlo- rophyll meter (SPAD-502; Konica Minolta Sensing, Tokyo, Japan). The average SPAD index of each plant was obtained from three measurements at three randomly selected locations on recently matured leaves outside leaf midribs, veins, and margins. Foliage coloration was quantified with a portable colorimeter (Chroma Meter CR-400; Konica Minolta Sensing) as the International Commission on Illumination $L^{*} a^{*} b^{*}$ color space coordinates. $L^{*}$ indicates leaf brightness, which ranges from 0 (darkest black) to 100 (brightest white). The positive directions of $a^{*}$ and $b^{*}$ indicate redness and yellowness, respectively, whereas their negative directions indicate greenness and blueness, respectively. The maximum quantum efficiency of photosystem II ( Fv/Fm) was measured on dark-adapted leaves (for $30 \mathrm{~min}$ ) with a multimode chlorophyll fluorometer (OS5p; Opti-Sciences, Hudson, NH).

Consumer sensory tests were performed at the Sensory Evaluation Laboratory of the Department of Food Science and Human Nutrition at Michigan State University based on the protocol described by Szczygiel et al. (2017). The protocol in 
Table 1. Spectral characteristics of nine sole-source lighting treatments delivered by mixtures of blue [B (400-500 nm)], green [G (500-600 nm)], and red [R (600-700 nm)], or warm-white (WW) light-emitting diodes (LEDs). ${ }^{\mathrm{z}}$

\begin{tabular}{|c|c|c|c|c|c|c|c|c|c|}
\hline & \multicolumn{9}{|c|}{ LED lighting treatment } \\
\hline & $\mathrm{R}_{180}$ & $\mathrm{G}_{60} \mathrm{R}_{120}$ & $\mathrm{~B}_{20} \mathrm{R}_{160}$ & $\mathrm{~B}_{20} \mathrm{G}_{60} \mathrm{R}_{100}$ & $\mathrm{~B}_{60} \mathrm{R}_{120}$ & $\mathrm{~B}_{60} \mathrm{G}_{60} \mathrm{R}_{60}$ & $\mathrm{~B}_{100} \mathrm{R}_{80}$ & $\mathrm{~B}_{100} \mathrm{G}_{60} \mathrm{R}_{20}$ & $\mathrm{WW}_{180}$ \\
\hline \multicolumn{10}{|c|}{ Single-band photon flux density $\left(\mu \mathrm{mol} \cdot \mathrm{m}^{-2} \cdot \mathrm{s}^{-1}\right)$} \\
\hline B & 0.1 & 3.4 & 19.6 & 24.3 & 58.6 & 62.1 & 99.6 & 103.1 & 12.1 \\
\hline G & 0.5 & 60.7 & 0.8 & 58.9 & 1.0 & 58.8 & 0.7 & 60.1 & 51.9 \\
\hline $\mathrm{R}$ & 180.1 & 120.8 & 158.9 & 99.1 & 121.9 & 57.5 & 83.1 & 23.2 & 98.4 \\
\hline FR & 1.6 & 1.5 & 1.8 & 1.2 & 1.3 & 0.7 & 0.8 & 0.4 & 18.6 \\
\hline \multicolumn{10}{|c|}{ Integrated photon flux density $\left(\mu \mathrm{mol} \cdot \mathrm{m}^{-2} \cdot \mathrm{s}^{-1}\right)$} \\
\hline$P P F D$ & 180.7 & 185.0 & 179.3 & 182.3 & 181.6 & 178.4 & 183.4 & 186.3 & 162.4 \\
\hline$T P F D$ & 182.3 & 186.5 & 181.1 & 183.5 & 182.9 & 179.1 & 184.2 & 186.7 & 181.0 \\
\hline$Y P F D$ & 167.7 & 162.8 & 163.1 & 156.5 & 158.2 & 146.1 & 151.8 & 145.4 & 148.9 \\
\hline \multicolumn{10}{|c|}{ Radiation ratio } \\
\hline $\mathrm{B}: \mathrm{R}$ & 0.0 & 0.0 & 0.1 & 0.2 & 0.5 & 1.1 & 1.2 & 4.5 & 0.1 \\
\hline$B: G$ & 0.2 & 0.1 & 25.6 & 0.4 & 58.4 & 1.1 & 137.9 & 1.7 & 0.2 \\
\hline $\mathrm{G}: \mathrm{R}$ & 0.0 & 0.5 & 0.0 & 0.6 & 0.0 & 1.0 & 0.0 & 2.6 & 0.5 \\
\hline $\mathrm{R}: \mathrm{FR}$ & 111.2 & 80.6 & 86.8 & 85.5 & 91.9 & 84.6 & 103.7 & 57.5 & 5.3 \\
\hline PPE & 0.883 & 0.882 & 0.880 & 0.876 & 0.869 & 0.855 & 0.855 & 0.796 & 0.828 \\
\hline \multicolumn{10}{|c|}{ Visual quality } \\
\hline CRI & 42 & 38 & -58 & 58 & -250 & 61 & -222 & 51 & 97 \\
\hline
\end{tabular}

${ }^{\mathrm{z}}$ The number following each waveband is its photon flux density in $\mu \mathrm{mol} \cdot \mathrm{m}^{-2} \cdot \mathrm{s}^{-1}$. Photon flux densities over 1-nm increments were integrated as the photosynthetic photon flux density $[P P F D$ $(400-700 \mathrm{~nm})]$ and the total photon flux density $[T P F D(400-800 \mathrm{~nm})]$, which includes far-red [FR $(700-800 \mathrm{~nm})]$ radiation. The yield photon flux density [YPFD $(300-800 \mathrm{~nm})]$ was the product of the spectral distribution and relative quantum efficiency (Sager et al., 1988). The phytochrome photoequilibrium (PPE) was estimated according to Sager et al. (1988). The color-rendering index (CRI) was calculated based on the spectral distribution using the online LED ColorCalculator (OSRAM Sylvania, 2019).

this study was approved by the Institutional Review Board of Michigan State University. On day 36 in replication 1 and day 32 in replication 2, organoleptic properties of lettuce leaves from six treatments $\left(\mathrm{R}_{180}, \mathrm{~B}_{20} \mathrm{R}_{160}, \mathrm{~B}_{20} \mathrm{G}_{60} \mathrm{R}_{100}, \mathrm{~B}_{100} \mathrm{R}_{80}, \mathrm{~B}_{100}\right.$ $\mathrm{G}_{60} \mathrm{R}_{20}$, and greenhouse) were evaluated by 86 and 78 sensory panelists of older than 18 years, respectively, who consumed lettuce at least once per month. A sensory analysis allowed testing of a limited number of treatments to achieve highquality results without panelist fatigue. The six treatments were selected for sensory and nutrient analyses because they represented key interactions between $B$ and $G$ radiation and provided for a comparison between the growth room and the greenhouse. The panelists were recruited using the Michigan State University Paid Research Pool by Sona Systems, Ltd. (Tallinn, Estonia). Each panelist was presented with six coded samples in random order and was asked to rate the overall acceptability, appearance, color, texture, overall flavor, and aftertaste using a 9-point hedonic scale, where $1=$ dislike extremely and $9=$ like extremely. The levels of bitterness and sweetness were measured using a 5-point Likert scale, where $1=$ not at all bitter (or sweet) and $5=$ extremely bitter (or sweet). How the samples met the expectations of red-leaf lettuce was measured using a 5point Likert scale, where $1=$ much worse than expected and $5=$ much better than expected. Willingness to buy was measured using a 5-point Likert scale, where $1=$ definitely would not purchase and $5=$ definitely would purchase. Subsequently, panelists were asked their age, gender, and consumption frequencies of lettuce, cruciferous vegetables, and coffee.

An elemental analysis was conducted at the U.S. Department of Agriculture Agricultural Research Service (Toledo, $\mathrm{OH}$ ) for lettuce leaf tissues from the same six treatments as those used for the sensory analysis. Dry tissues were ground using a mortar and pestle. Foliar nitrogen content was measured with a $\mathrm{CHN}$ analyzer (vario MICRO cube; Elementar, Hanau, Germany) using $\approx 2.5 \mathrm{mg}$ dry lettuce tissue in tin capsules (EA Consumables, Pennsauken, NJ). Other macronutrients and micronutrients were quantified with inductively coupled plasma optical emission spectrometry (iCAP 6300 Duo ICP-OES Analyzer; Thermo Fisher Scientific, Waltham, MA) based on the modified U.S. Environmental Protection Agency method 3051 with an extra hydrogen peroxide step. Spinach (Spinacia oleracea) leaves [National Institute of Standards and Technology (NIST) standard reference material 1570a] were included for every 20 samples. Peach (Prunus persica) leaves (NIST standard reference material 1547) were included for every 40 samples. Five milliliters of nitric acid was combined with $\approx 0.25 \mathrm{~g}$ dry lettuce tissue in a polytetrafluoroethylene-based vessel (Teflon; The Chemours Co., Wilmington, DE). Samples were placed in a microwave for digestion (MARS 6; CEM Corp., Matthews, NC); the temperature was increased to $200{ }^{\circ} \mathrm{C}$ within $15 \mathrm{~min}$, maintained at $200{ }^{\circ} \mathrm{C}$ for $15 \mathrm{~min}$, and then decreased to room temperature. After the addition of $1.5 \mathrm{~mL}$ of hydrogen peroxide to each sample, samples were reheated to $200{ }^{\circ} \mathrm{C}$ and remained at that temperature for $5 \mathrm{~min}$; then, they were cooled to room temperature. Samples were filtered (Whatman qualitative filter paper, Grade 2; Whatman, Maidstone, UK) after the addition of $12 \mathrm{~mL}$ of $18 \mathrm{M} \Omega$ water to each sample. A $1.3-\mathrm{mL}$ aliquot of the solution was diluted with $8.7 \mathrm{~mL}$ of $18 \mathrm{M} \Omega$ water for the elemental analysis in the ICP-OES analyzer.

The experiment was performed twice and followed a randomized complete block design. All data were pooled from two replications because the treatment $\times$ replication interaction was not significant $(P>0.05)$ or the response trends were similar between replications. Data were analyzed using SAS (version 9.4; SAS Institute, Cary, NC) with the PROC MEANS, PROC MIXED, and PROC GLIMMIX procedures and Tukey's honestly significant difference test $(\alpha=0.05)$. Photographs of a representative plant from each treatment were obtained to show visual differences (Fig. 2).

\section{Results}

Biomass. Irrespective of the presence of $\mathrm{G}$ radiation, there were linear negative relationships between the $\mathrm{B} P F D$ and biomass accumulation. At a $P P F D$ of $180 \mu \mathrm{mol} \cdot \mathrm{m}^{-2} \cdot \mathrm{s}^{-1}$, increasing the B PFD from 0 to $100 \mu \mathrm{mol} \cdot \mathrm{m}^{-2} \cdot \mathrm{s}^{-1}$ decreased shoot fresh and dry mass by $58 \%$ and $46 \%$, respectively, in an $\mathrm{R}$ radiation 

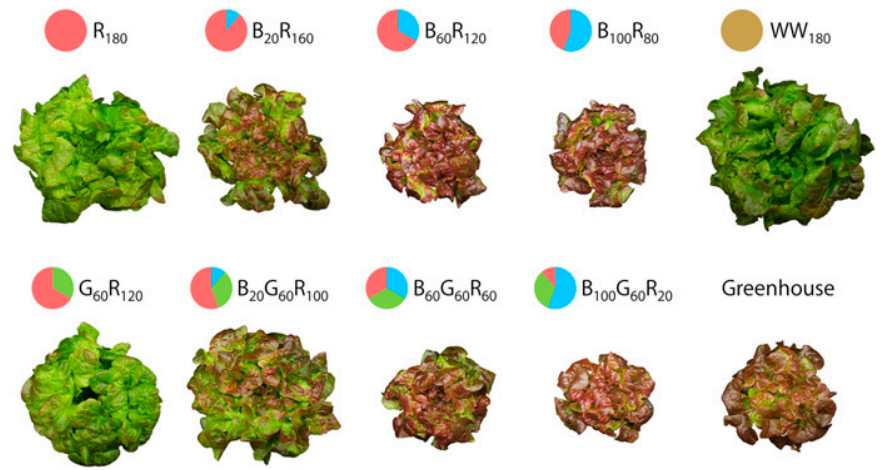

Greenhouse

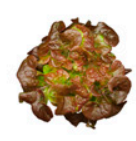

Fig. 2. 'Rouxai' lettuce $32 \mathrm{~d}$ after sowing from the first replication. Plants were grown under nine sole-source lighting treatments delivered by mixtures of blue [B (400-500 nm)], green [G (500-600 nm)], and red [R (600-700 nm)], or warm-white (WW) light-emitting diodes or a greenhouse treatment that received sunlight supplemented with high-pressure sodium lighting. The number following each waveband is its photon flux density in $\mu \mathrm{mol} \cdot \mathrm{m}^{-2} \cdot \mathrm{s}^{-1}$.

background and by $63 \%$ and $54 \%$, respectively, with 60 $\mu \mathrm{mol} \cdot \mathrm{m}^{-2} \cdot \mathrm{s}^{-1}$ of $\mathrm{G}$ radiation as substitution of $\mathrm{R}$ radiation (Fig. 3 ). The effects of $\mathrm{G}$ radiation varied depending on the $\mathrm{B} P F D . \mathrm{G}$ radiation did not influence the shoot fresh mass when $B$ radiation was absent, increased it by $18 \%$ at $\mathrm{B}_{20}$, and decreased it by $29 \%$ and $19 \%$ at $B_{60}$ and $B_{100}$, respectively. $G$ radiation did not influence the shoot dry mass at $\mathrm{B}_{0}$ or $\mathrm{B}_{20}$, but it decreased it by $26 \%$ and $20 \%$ at $B_{60}$ and $B_{100}$, respectively. The shoot fresh or dry mass was similar under $\mathrm{WW}_{180}$ and $\mathrm{G}_{60} \mathrm{R}_{120}$. Plants grown in the greenhouse had shoot fresh and dry mass comparable to those grown under $\mathrm{B}_{100} \mathrm{R}_{80}$, although they received higher DLIs.

Morphology. Increasing the B PFD in the presence of $\mathrm{G}$ radiation decreased leaf length linearly by up to $17 \%$ (Fig. 3). Without $G$ radiation, leaf length decreased by $13 \%$ from $B_{0}$ to $\mathrm{B}_{20}$, but it did not change beyond $\mathrm{B}_{20}$. Substituting $\mathrm{R}$ radiation with $\mathrm{G}$ radiation did not affect leaf length at any $\mathrm{B} P F D$ delivered. Plants grown under $\mathrm{WW}_{180}$ and in the greenhouse had leaf length similar to those grown under $R_{180}$ and $G_{60} R_{120}$. Increasing the B PFD from 0 to $100 \mu \mathrm{mol} \cdot \mathrm{m}^{-2} \cdot \mathrm{s}^{-1}$ decreased leaf width by $34 \%$ and $29 \%$ with and without $G$ radiation, respectively. Leaf width was similar with or without $G$ radiation at $\mathrm{B}_{0}, \mathrm{~B}_{20}$, and $\mathrm{B}_{60}$, but it was $9 \%$ lower with $\mathrm{G}$ radiation at $B_{100}$. Leaves were widest under $R_{180}, G_{60} R_{120}$, and $W_{180}$; they were narrowest under $\mathrm{B}_{100} \mathrm{G}_{60} \mathrm{R}_{20}$ and in the greenhouse. Plant diameter decreased linearly with an increasing $\mathrm{B} P F D$ by up to $21 \%$ with $G$ radiation and $18 \%$ without $G$ radiation. $G$ radiation decreased plant diameter by $9 \%$ at $\mathrm{B}_{60}$, but it did not affect it at the other $\mathrm{B} P F D \mathrm{~s}$. Without $\mathrm{G}$ radiation, plants had two or three more leaves at $B_{0}$ than at $B_{20}$ and $B_{100}$. In the presence of $\mathrm{G}$ radiation, plants developed three more leaves at $\mathrm{B}_{0}$ and $\mathrm{B}_{20}$ (and under $\mathrm{WW}_{180}$ ) than at $\mathrm{B}_{60}$ and $\mathrm{B}_{100}$ (and in the greenhouse). Substituting $G$ radiation for $R$ radiation increased leaf number by three at $\mathrm{B}_{20}$, but not at the other $\mathrm{B} P F D$ s.

SPAD AND Fv/FM. With or without $G$ radiation, increasing the B PFD from 0 to $20 \mu \mathrm{mol} \cdot \mathrm{m}^{-2} \cdot \mathrm{s}^{-1}$ increased the SPAD index by $12 \%$ to $13 \%$ and saturated this response (Fig. 3). The inclusion of $\mathrm{G}$ radiation decreased the SPAD index by $9 \%$ at $\mathrm{B}_{60}$, but not at the other $\mathrm{B} P F D$. Increasing the $\mathrm{B} P F D$ from 0 to $100 \mu \mathrm{mol} \cdot \mathrm{m}^{-2} \cdot \mathrm{s}^{-1}$ did not affect $\mathrm{Fv} / \mathrm{Fm}$ in the absence of $\mathrm{G}$ radiation, but it increased it by $3 \%$ in the presence of $G$ radiation. $\mathrm{Fv} / \mathrm{Fm}$ was similar under $\mathrm{WW}_{180}$ and at $\mathrm{B}_{0}$ and $\mathrm{B}_{20}$, and it was similar in the greenhouse and at $\mathrm{B}_{100}$.
Foliage COlORATION. With or without $\mathrm{G}$ radiation, increasing the B PFD from 0 to $20 \mu \mathrm{mol} \cdot \mathrm{m}^{-2} \cdot \mathrm{s}^{-1}$ decreased brightness $\left(L^{*}\right)$ and yellowness $\left(b^{*}\right)$ and increased redness $\left(a^{*}\right)$ of foliage directly exposed to radiation (Figs. 2 and 4). Colors generally saturated with $20 \mu \mathrm{mol} \cdot \mathrm{m}^{-2} \cdot \mathrm{s}^{-1}$ of B radiation; however, in the presence of $G$ radiation, foliage redness saturated at 60 $\mu \mathrm{mol} \cdot \mathrm{m}^{-2} \cdot \mathrm{s}^{-1}$ of $\mathrm{B}$ radiation. Substituting $\mathrm{G}$ radiation for $\mathrm{R}$ radiation did not influence foliage coloration at any $\mathrm{B} P F D$. Foliage coloration of plants grown under $\mathrm{WW}_{180}$, which included $\mathrm{B}_{12}$, was between that of the $\mathrm{B}_{0}$ and $\mathrm{B}_{20}$ treatments. Plants grown in the greenhouse had foliage coloration similar to those grown at $\mathrm{B}_{100} \mathrm{R}_{80}$.

SENSORY ATTRIBUTES. Regardless of differences in leaf color, plant appearance and color were rated similarly by panelists across all tested treatments (Fig. 5). Substituting $G$ radiation for $R$ radiation did not influence any sensory attribute at $B_{20}$ or $\mathrm{B}_{100}$. Ratings of overall acceptability, flavor, aftertaste, meeting expectations, and willingness to buy were $9 \%$ to $13 \%, 15 \%$ to $18 \%, 15 \%$ to $17 \%, 13 \%$ to $19 \%$, and $15 \%$ to $20 \%$ lower, respectively, for greenhouse-grown plants than for plants grown under the five sole-source lighting treatments. These sensory attributes were similar under the five sole-source lighting treatments. Leaf texture was rated $6 \%$ lower under $\mathrm{B}_{100}$ $\mathrm{G}_{60} \mathrm{R}_{20}$ than under $\mathrm{R}_{180}$. Bitterness of greenhouse-grown plants was rated $37 \%$ to $50 \%$ higher than that under the five solesource lighting treatments. In the absence of $\mathrm{G}$ radiation, increasing the B PFD from 0 to $100 \mu \mathrm{mol} \cdot \mathrm{m}^{-2} \cdot \mathrm{s}^{-1}$ decreased the sweetness rating by $14 \%$. Sweetness was rated similarly low for plants grown in the greenhouse and under $B_{100} G_{60} R_{20}$.

Essential NUTRIENTS. There were no treatment effects on phosphorus, calcium, iron, and boron concentrations (Fig. 6). Substituting $G$ radiation for $R$ radiation at $B_{20}$ or $B_{100}$ did not affect any macronutrient or micronutrient concentrations. In the absence of $\mathrm{G}$ radiation, increasing the $\mathrm{B} P F D$ from 0 to 100 $\mu \mathrm{mol} \cdot \mathrm{m}^{-2} \cdot \mathrm{s}^{-1}$ increased nitrogen, magnesium, sulfur, zinc, and copper concentrations by $15 \%, 10 \%, 19 \%, 19 \%$, and $45 \%$, respectively, but it did not affect the other nutrient concentrations. With $\mathrm{G}$ radiation, increasing the B PFD from 20 to 100 $\mu \mathrm{mol} \cdot \mathrm{m}^{-2} \cdot \mathrm{s}^{-1}$ increased nitrogen and sulfur concentrations by $10 \%$ and $29 \%$, respectively, but it did not influence the other nutrient concentrations. Plants grown in the greenhouse were $22 \%$ to $26 \%, 44 \%$ to $54 \%$, and $61 \%$ to $70 \%$ lower in potassium, manganese, and molybdenum concentrations, respectively, and $36 \%$ to $71 \%$ higher in magnesium concentration compared with those grown under five sole-source lighting treatments. The nitrogen concentration in greenhouse-grown plants was similar to that under $\mathrm{R}_{100}$ and $\mathrm{B}_{20} \mathrm{R}_{160}$. The sulfur, zinc, and copper concentrations in greenhouse-grown plants were similar to those under $\mathrm{B}_{100} \mathrm{G}_{60} \mathrm{R}_{20}$.

\section{Discussion}

Meng et al. (2019) reported that the incremental substitutions of $G$ radiation for $B$ radiation in $B_{60} R_{120}$ increased the biomass and leaf expansion of 'Rex' lettuce, 'Rouxai' lettuce, and 'Siberian' kale. Similarly, substituting $14 \mu \mathrm{mol} \cdot \mathrm{m}^{-2} \cdot \mathrm{s}^{-1}$ of $G$ radiation for $B_{42}$ or $B_{60}$ in an $R$ radiation background increased fresh and dry mass and leaf area of 'Sunmang' redleaf lettuce (Son and Oh, 2015). However, because B radiation was not kept constant, increased plant growth could be attributed to diminishing $B$ radiation rather than increasing $G$ radiation. In the present study, $G$ radiation as substitution of 


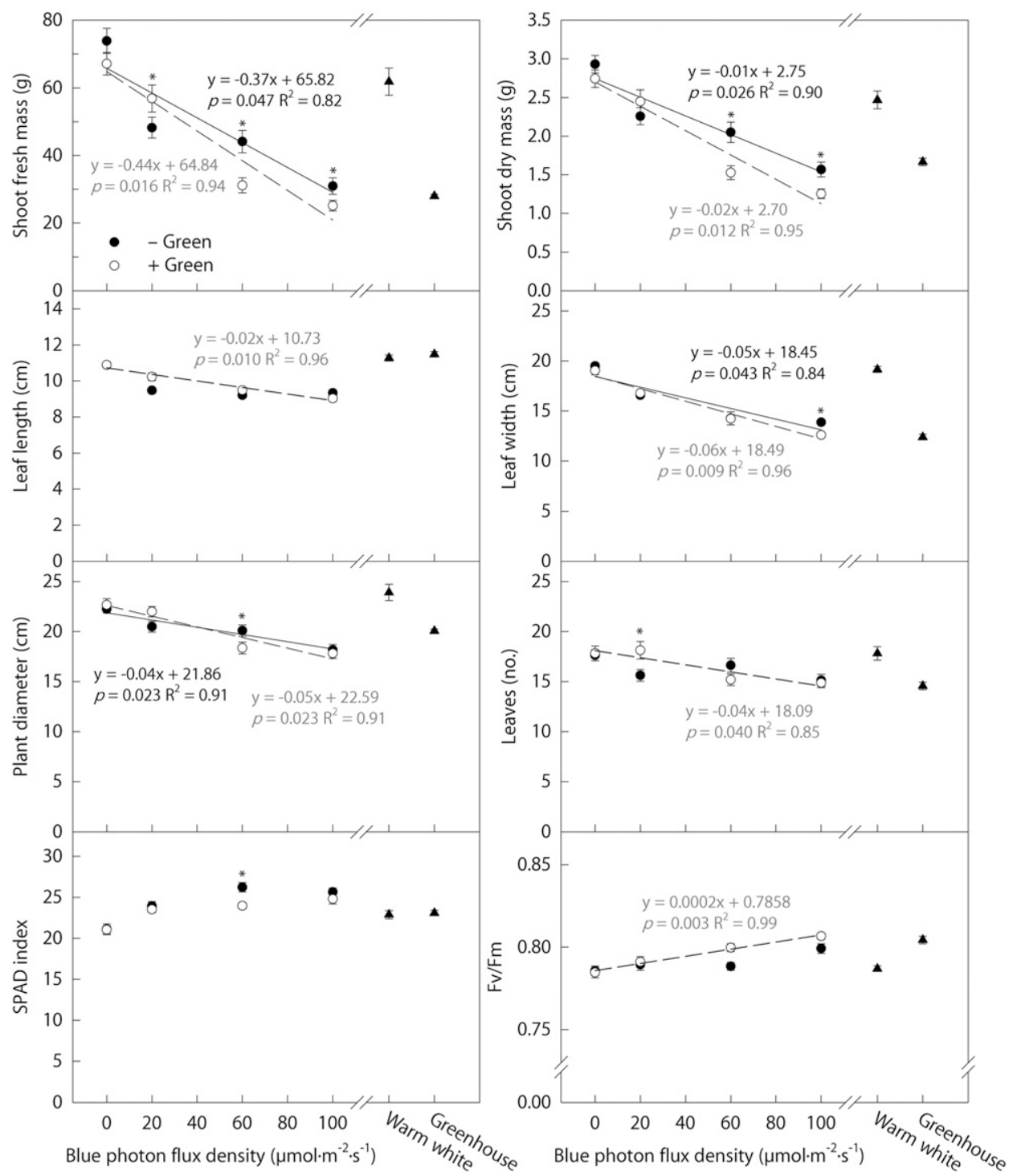

Fig. 3. Shoot fresh and dry mass, leaf length and width, plant diameter, leaf number, the SPAD index, and maximum quantum efficiency of photosystem II ( $\mathrm{Fv} / \mathrm{Fm})$ of 'Rouxai' lettuce grown under nine sole-source lighting treatments, with or without green radiation, or in a greenhouse. Equations, $P$ values, and coefficients of determination $\left(R^{2}\right)$ are given for linear responses to the blue photon flux density $(\alpha=0.05)$ with green radiation (solid lines and black text) and without green radiation (dashed lines and gray text). At any blue photon flux density, an asterisk indicates means with and without green radiation are significantly different based on Tukey's honestly significant difference test $(\alpha=0.05)$. Error bars show SE.

$\mathrm{R}$ radiation had variable effects at multiple fixed $\mathrm{B} P F D$ s. In the absence of $B$ radiation, $G$ radiation did not influence any parameters measured. Under low $B$ radiation $\left(B_{20}\right), G$ radiation increased the shoot fresh mass and leaf number. Under moderate $\mathrm{B}$ radiation $\left(\mathrm{B}_{60}\right), \mathrm{G}$ radiation decreased the shoot fresh and dry mass, plant diameter, and SPAD index. Under high B radiation $\left(B_{100}\right), G$ radiation decreased the shoot fresh and dry mass and leaf width. This interaction between $B$ and $G$ radiation is a novel discovery that adds complexity to spectral responses in plants, although the changing $\mathrm{R} P F D$ could also be part of the interaction. A similar study confirmed that increasing the $\mathrm{B}$ $P F D$ from 0 to $45 \mu \mathrm{mol} \cdot \mathrm{m}^{-2} \cdot \mathrm{s}^{-1}$ decreased lettuce growth and leaf expansion, but there were no effects of $15 \mu \mathrm{mol} \cdot \mathrm{m}^{-2} \cdot \mathrm{s}^{-1}$ of $\mathrm{G}$ radiation at the $\mathrm{B} P F D$ s tested (Kang et al., 2016). In comparison, the dependence of $\mathrm{G}$ radiation effects on the $\mathrm{B}$
PFD was found in our study using a wider range of $\mathrm{B} P F D \mathrm{~s}$ (between 0 and $\left.100 \mu \mathrm{mol} \cdot \mathrm{m}^{-2} \cdot \mathrm{s}^{-1}\right)$ and higher $\mathrm{G}$ PFD $\left(60 \mu \mathrm{mol} \cdot \mathrm{m}^{-2} \cdot \mathrm{s}^{-1}\right)$.

The minimal effects of $\mathrm{G}$ radiation under low $\mathrm{B}$ radiation were consistent with some previous studies. For example, at a PPFD of 173 $\mu \mathrm{mol} \cdot \mathrm{m}^{-2} \cdot \mathrm{s}^{-1}$, substituting 17 $\mu \mathrm{mol} \cdot \mathrm{m}^{-2} \cdot \mathrm{s}^{-1}$ of $\mathrm{R}$ radiation with $\mathrm{G}$ radiation did not influence the biomass and leaf area of 'Grand Rapids TBR' lettuce at $\mathrm{B}_{22}$ and $\mathrm{B}_{42}$, although it increased those of 'Sunmang' lettuce at $\mathrm{B}_{42}$, but not at $\mathrm{B}_{22}$ (Son and $\mathrm{Oh}, 2015$ ). The low G PFD $\left(\mathrm{G}_{17}\right)$ was regarded as less effective than a higher one $\left(\mathrm{G}_{36}\right)$ at promoting growth rates in a quantitative manner; however, the high $\mathrm{G} P F D\left(\mathrm{G}_{60}\right)$ in our study marginally influenced growth under low $\mathrm{B}$ radiation. In addition, $\mathrm{G}$ radiation in $\mathrm{B}_{20} \mathrm{G}_{28} \mathrm{R}_{52}$ was interpreted as neither promotive nor inhibitory for the growth and morphology of cucumber 'Cumlaude' because the data fit the dose-response relationships with the B PFD, although $\mathrm{B}_{20} \mathrm{R}_{80}$ was not provided as a direct comparison (Hernández and Kubota, 2016). Similarly, under low B radiation (21-28 $\left.\mu \mathrm{mol} \cdot \mathrm{m}^{-2} \cdot \mathrm{s}^{-1}\right)$, increasing the $\mathrm{G} P F D$ from 3 to $82 \mu \mathrm{mol} \cdot \mathrm{m}^{-2} \cdot \mathrm{s}^{-1}$ at a $P P F D$ of $200 \mu \mathrm{mol} \cdot \mathrm{m}^{-2} \cdot \mathrm{s}^{-1} \mathrm{did}$ not affect dry mass or net assimilation of 'Waldmann's Green' lettuce (Snowden et al., 2016). Although these findings suggested $\mathrm{G}$ radiation neither promoted nor suppressed plant growth, other studies indicated positive or negative roles of $\mathrm{G}$ radiation under low $\mathrm{B}$ radiation. For example, substituting 36 $\mu \mathrm{mol} \cdot \mathrm{m}^{-2} \cdot \mathrm{s}^{-1}$ of $\mathrm{R}$ radiation in $\mathrm{B}_{24}$ $\mathrm{R}_{126}$ (from LEDs) with $\mathrm{G}$ radiation (from filtered fluorescent lamps) increased the leaf area, shoot fresh mass, and shoot dry mass of 'Waldmann's Green' lettuce (Kim et al., 2004); however, these results could be confounded by increases in diffuse radiation or leaf temperature due to the use of green fluorescent lamps (Snowden et al., 2016). On the contrary, substituting $\mathrm{G}$ radiation for half the $\mathrm{R}$ radiation in $\mathrm{R}_{160}$ decreased leaf area and shoot fresh and dry mass of tomato (Solanum lycopersicum 'Early Girl'), salvia (Salvia splendens 'Vista Red'), and petunia (Petunia $\times$ hybrida 'Wave Pink') seedlings, but not impatiens (Impatiens walleriana 'SuperElfin XP Red') seedlings (Wollaeger and Runkle, 2014). This indicated that different plant species can have various responses to $G$ radiation.

In the present study, at the same PPFD, substituting $\mathrm{G}$ radiation for $\mathrm{R}$ radiation decreased biomass accumulation 


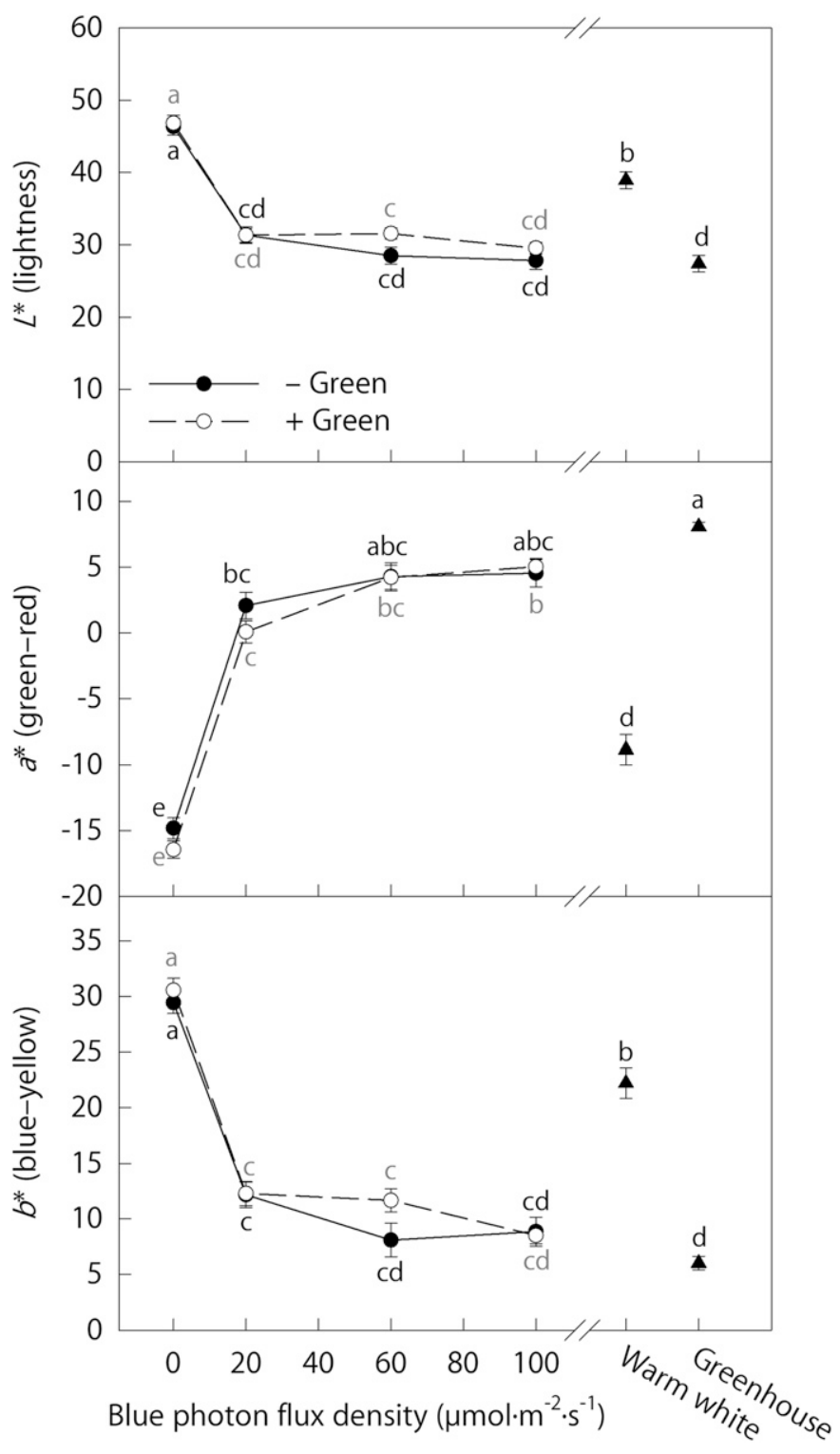

Fig. 4. $L^{*} a^{*} b^{*}$ color space analysis of 'Rouxai' lettuce grown under nine solesource lighting treatments, with or without green radiation, or in a greenhouse. $L^{*}$ indicates lightness, ranging from 0 (the darkest black) to 100 (the brightest white). $a^{*}$ indicates redness in the positive direction and greenness in the negative direction. $b^{*}$ indicates yellowness in the positive direction and blueness in the negative direction. Means followed by different letters within each parameter are significantly different based on Tukey's honestly significant difference test $(\alpha=0.05)$. Black and gray letters are associated with filled circles (without green radiation) and empty circles (with green radiation), respectively. Error bars show SE.

under moderate to high $\mathrm{B}$ radiation. This could be explained, at least partly, by photosynthetic differences. Substituting 15 $\mu \mathrm{mol} \cdot \mathrm{m}^{-2} \cdot \mathrm{s}^{-1}$ of $\mathrm{G}$ radiation for $\mathrm{R}$ radiation at a $P P F D$ of 150 $\mu \mathrm{mol} \cdot \mathrm{m}^{-2} \cdot \mathrm{s}^{-1}$ decreased the photosynthetic rate of 'Green Skirt' lettuce at $\mathrm{B}_{15}, \mathrm{~B}_{30}$, and $\mathrm{B}_{45}$ (but increased it at $\mathrm{B}_{0}$ ), although it did not affect leaf shape or plant growth (Kang et al., 2016). However, the photosynthetic rate of 'Waldmann's Green' lettuce was similar with and without $\mathrm{G}$ radiation at $\mathrm{B}_{24}(\mathrm{Kim}$ et al., 2004). In our study, substituting $60 \mu \mathrm{mol} \cdot \mathrm{m}^{-2} \cdot \mathrm{s}^{-1}$ of $\mathrm{G}$ radiation for $\mathrm{R}$ radiation decreased the $Y P F D$ at $\mathrm{B}_{0}, \mathrm{~B}_{20}, \mathrm{~B}_{60}$, and $\mathrm{B}_{100}$ by $3 \%, 4 \%, 8 \%$, and $4 \%$, respectively. Therefore, less
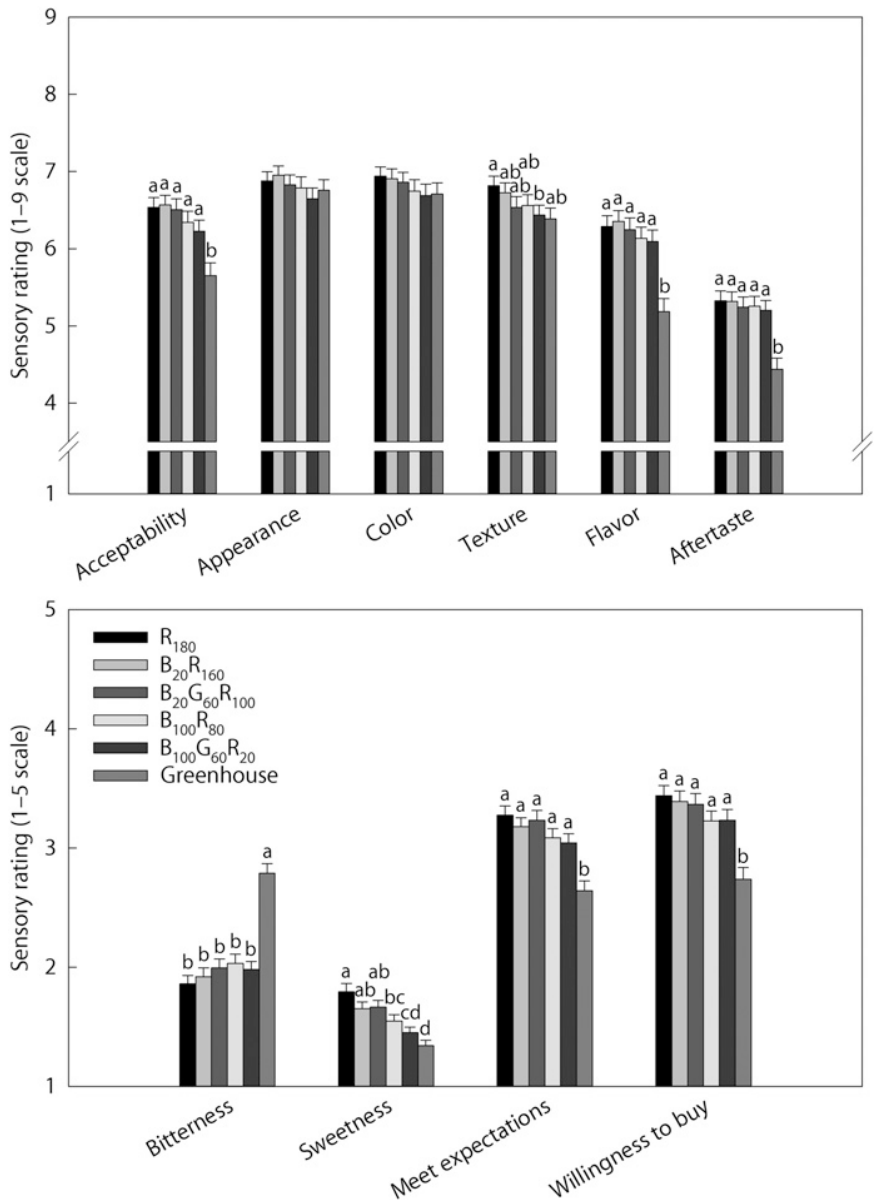

Fig. 5. Sensory ratings of 'Rouxai' lettuce by 164 panelists ( 86 and 78 in two replications). The upper panel shows sensory ratings on a scale of 1 (dislike extremely) to 9 (like extremely). The lower panel shows sensory ratings on a scale of 1 (low) to 5 (high). Plants were grown under five sole-source lighting treatments or in a greenhouse. The number for each waveband \{blue [B (400$500 \mathrm{~nm})]$, green $[\mathrm{G}(500-600 \mathrm{~nm})]$, or red $[\mathrm{R}(600-700 \mathrm{~nm})]\}$ is its photon flux density in $\mu \mathrm{mol} \cdot \mathrm{m}^{-2} \cdot \mathrm{s}^{-1}$. Means followed by different letters within each category are significantly different based on Tukey's honestly significant difference test $(\alpha=0.05)$. Error bars show SE.

biomass with $\mathrm{G}$ radiation at $\mathrm{B}_{60}$ can be attributed to a lower $Y P F D$, as well as reduced plant diameter and chlorophyll content, which reduced both radiation interception and photosynthesis. Growth inhibition under $\mathrm{G}$ radiation at $\mathrm{B}_{100}$ was mainly associated with reduced leaf width and, thus, radiation interception rather than the small decrease in the $Y P F D$, which did not affect shoot dry mass or leaf expansion at $\mathrm{B}_{0}$ and $\mathrm{B}_{20}$. These results substantiate a previous notion that $\mathrm{G}$ radiation, when added to $\mathrm{B}+\mathrm{R}$ radiation, can negatively influence plant growth (Folta and Maruhnich, 2007; Went, 1957). In contrast, butterhead lettuce grown under $\mathrm{B}_{40} \mathrm{R}_{160}$ and $\mathrm{B}_{67} \mathrm{G}_{67} \mathrm{R}_{67}$ with a 12-h photoperiod had similar shoot fresh mass, leaf area, and leaf number (Bian et al., 2018). These plants were grown under white fluorescent lamps until day 14 and received lighting treatments at a DLI of $8.6 \mathrm{~mol} \cdot \mathrm{m}^{-2} \cdot \mathrm{d}^{-1}$ from days 14 to 34 . However, in our study, lighting treatments were applied to plants earlier, longer (from day 4 to day 30 or 33 ), and at a $50 \%$ higher DLI, which could cause different responses.

The relative growth rate of a plant is a function of its leaf area ratio and the net assimilation rate (Lambers et al., 2008). 

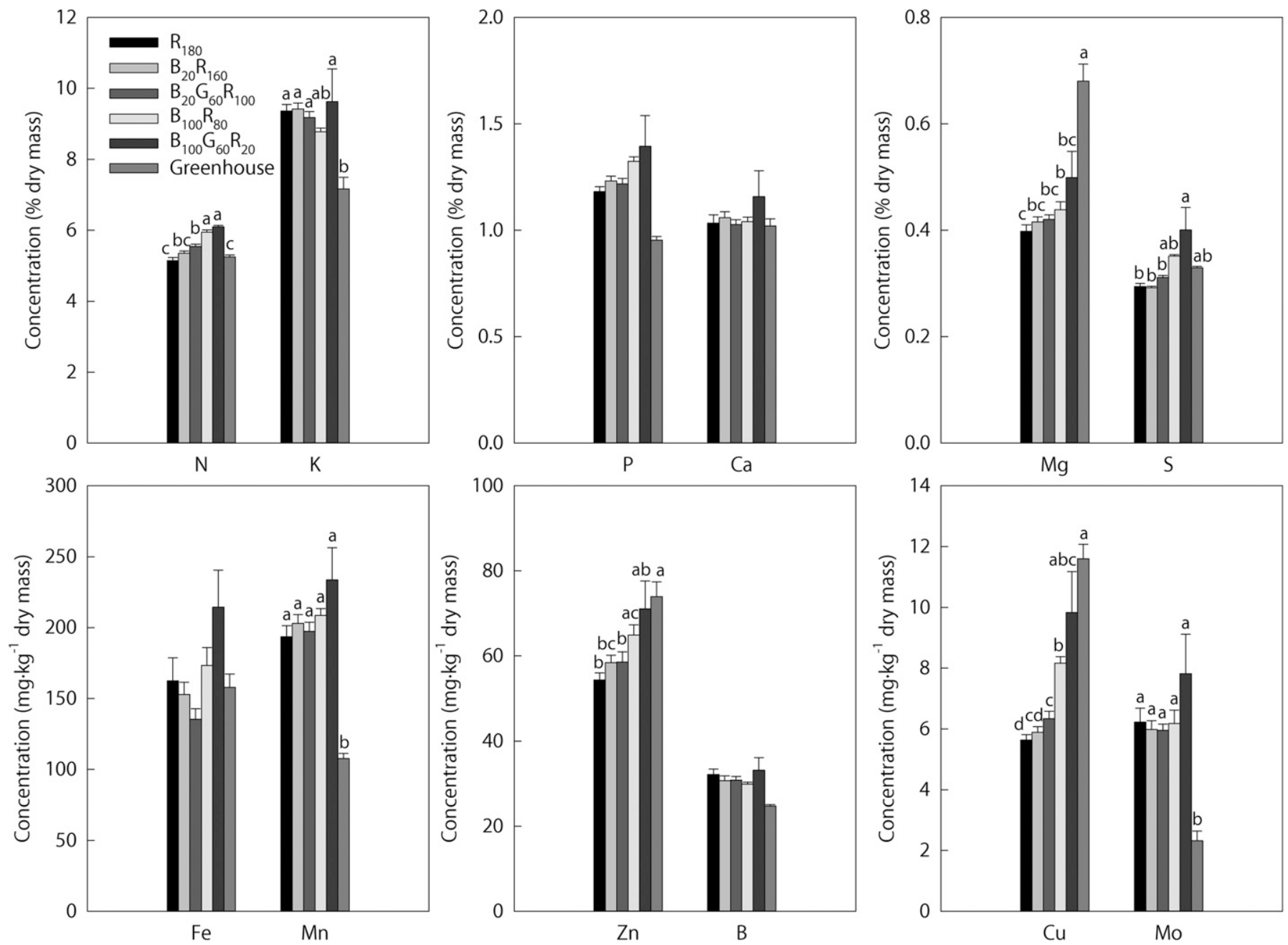

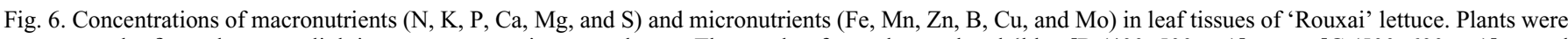
grown under five sole-source lighting treatments or in a greenhouse. The number for each waveband $\{$ blue [B (400-500 $\mathrm{nm})]$, green $[\mathrm{G}(500-600 \mathrm{~nm})]$, or red $[\mathrm{R}(600-700 \mathrm{~nm})]\}$ is its photon flux density in $\mu \mathrm{mol} \cdot \mathrm{m}^{-2} \cdot \mathrm{s}^{-1}$. Means followed by different letters within each element are significantly different based on Tukey's honestly significant difference test $(\alpha=0.05)$. Error bars show SE.

The leaf area ratio indicates the amount of leaf area available for radiation capture to drive photosynthesis relative to the plant mass. In this study, reduced plant size (i.e., leaf length, leaf width, and plant diameter) was generally associated with reduced biomass accumulation. Increasing the B PFD linearly decreased shoot fresh and dry mass as well as leaf width and plant diameter of 'Rouxai' lettuce, showing B radiation suppression of yield and extension growth. Similarly, incremental substitutions of $\mathrm{B}$ radiation for $\mathrm{R}$ radiation (from 0 to 100 $\mu \mathrm{mol} \cdot \mathrm{m}^{-2} \cdot \mathrm{s}^{-1}$ at a $P P F D$ of $171 \mu \mathrm{mol} \cdot \mathrm{m}^{-2} \cdot \mathrm{s}^{-1}$ ) decreased the shoot fresh and dry mass of 'Sunmang' red-leaf lettuce by up to $71 \%$ and $61 \%$, respectively, and decreased leaf area by up to $72 \%$ (Son and Oh, 2013). In our study, B radiation decreased leaf width more than leaf length, indicating that inhibitory effects of $\mathrm{B}$ radiation on leaf expansion were unequal in transverse directions. The observed responses to $\mathrm{B}$ radiation in our study can be explained by the roles of cryptochromes in modulating the shade-avoidance response. Plants use photoreceptors, such as cryptochromes, to gauge the incident B PFD (Casal, 2000; Lin, 2000). Extension growth in response to the B $P F D$ is mediated by dynamic, direct interactions between cryptochromes and phytochrome-interacting factors (PIFs), which are basic helix-loop-helix transcription factors (Pedmale et al., 2016). At a low B PFD, cryptochromes 1 and 2 interact with PIFs 4 and 5 to promote the expression of growth-related genes, whereas at a high B PFD, suppression of PIFs 4 and 5 by cryptochromes and proteasomal degradation of cryptochrome 2 and PIF5 together inhibit extension growth (Pedmale et al., 2016). Reduced B PFDs can elicit the shade-avoidance response, such as stem and hypocotyl elongation and hyponasty, involving the regulation of DELLA proteins through gibberellin, control of auxin, and changes in cell wall extensibility through expansins and xyloglucan endotransglucosylase/hydrolases (DjakovicPetrovic et al., 2007; Pierik et al., 2004, 2009; Sasidharan et al., 2008).

In most cases, $B$ radiation inhibits stem elongation and leaf expansion; however, the effects of $\mathrm{B}$ radiation on extension growth in some studies were inconsistent with this paradigm, possibly because of confounding wavebands, interacting factors, or species- or cultivar-specific sensitivity. For example, using high-pressure sodium and metal halide lamps, increasing the $\mathrm{B}$ radiation fraction from $6 \%$ to $26 \%$ decreased cell 
expansion and, thus, leaf expansion in soybean (Glycine max 'Hoyt'); however, increasing the B radiation fraction from $0 \%$ to $6 \%$ increased cell expansion and division in 'Grand Rapids' lettuce (Dougher and Bugbee, 2004). Filter conversion of B radiation to yellow radiation $(580-600 \mathrm{~nm})$ to achieve $0 \% \mathrm{~B}$ radiation might be a confounding factor because yellow radiation appeared to suppress lettuce growth (Dougher and Bugbee, 2001). In a subsequent study, changing the B radiation fraction between $11 \%$ and $28 \%$ did not influence the leaf area index or dry mass of 'Waldmann's Green' lettuce (Snowden et al., 2016), although other wavebands (e.g., $\mathrm{G}$ and $\mathrm{R}$ radiation) could have confounded the outcomes because $\mathrm{B}$ radiation was emitted from broad-spectrum LEDs. Cucumber 'Cumlaude' grown under $100 \% \mathrm{~B} \mathrm{LEDs} \mathrm{at} 100 \mu \mathrm{mol} \cdot \mathrm{m}^{-2} \cdot \mathrm{s}^{-1}$ were taller than those grown under $\mathrm{R}$ or $\mathrm{R}+\mathrm{B}$ LEDs and had a greater leaf area than those grown under $B_{75} R_{25}$ (Hernández and Kubota, 2016). The lack of growth inhibition under $100 \% \mathrm{~B}$ radiation was partly attributed to a low phytochrome photoequilibrium of 0.5 (Hernández and Kubota, 2016); however, 100\% B radiation suppressed leaf expansion and decreased the shoot dry mass of lettuce (cultivar unspecified) and 'Vista Red' salvia (Wang et al., 2016; Wollaeger and Runkle, 2015). Therefore, atypical sensitivity of specific species and cultivars to $\mathrm{B}$ radiation alone is possible.

Although $G$ radiation can elicit the shade-avoidance response (Wang and Folta, 2013; Zhang and Folta, 2012; Zhang et al., 2011), there was no evidence it did so in this study. First, growth and morphological responses to $\mathrm{G}$ radiation can change dynamically depending on plant age, which may contribute to some discrepancies in previous studies of plants in different developmental stages. For example, partial substitution of white radiation $\left(\mathrm{B}_{37} \mathrm{G}_{86} \mathrm{R}_{58}\right)$ with $\mathrm{G}$ radiation $\left(\mathrm{B}_{31} \mathrm{G}_{104} \mathrm{R}_{45}\right)$ increased the fresh and dry mass and shoot diameter of 'Outredgeous' lettuce 14 and $21 \mathrm{~d}$ after sowing, but it did not affect the fresh and dry mass or leaf area on day 28 (Mickens et al., 2018). Therefore, plants harvested on days 30 and 33 in our study may be less responsive to $\mathrm{G}$ radiation in the maturation phase than in the lag phase. Second, low B radiation is a strong shade signal that may saturate the shade-avoidance response (Keuskamp et al., 2011; Pierik et al., 2004), rendering additional $\mathrm{G}$ radiation futile in morphological control. Third, the predominant suppression of extension growth by high $\mathrm{B}$ radiation may override weaker control of extension growth by $G$ radiation. For example, leaf area, shoot fresh mass, or shoot dry mass of 'SuperElfin XP Red' impatiens, 'Vista Red' salvia, or 'Wave Pink' petunia seedlings was similar under $\mathrm{B}_{160}$ and $\mathrm{B}_{80}$ $\mathrm{G}_{80}$ (Wollaeger and Runkle, 2014).

Taken together with antagonism between $\mathrm{B}$ and $\mathrm{G}$ radiation with fixed $\mathrm{R}$ radiation reported by Meng et al. (2019), the effects of $\mathrm{G}$ radiation depend on the specific spectral context. Without the shade-avoidance response as a confounding factor under moderate or high $B$ radiation, $G$ radiation was evidently less effective than $\mathrm{R}$ radiation at promoting lettuce growth. This is supported by observations that $\mathrm{G}$ radiation is less effective than $\mathrm{R}$ radiation at driving photosynthesis (Hogewoning et al., 2012; Kang et al., 2016; McCree, 1972). Therefore, the comparable effectiveness of $G$ and $R$ radiation with little or no $B$ radiation can be attributed to a strong shade-avoidance signal, which $G$ radiation either sustained or at least did not negate. Morphological adaptation to this signal overrode different photosynthetic efficacies between $G$ and $R$ radiation, resulting in similar whole-plant photosynthesis. Isolating the role of $\mathrm{G}$ radiation in the low $B$ radiation-induced shade-avoidance response warrants further investigation.

Increasing the DLI typically increases the shoot dry mass of lettuce (Both et al., 1997; Kitaya et al., 1998). However, shoot dry mass was similarly low for plants grown under $\mathrm{B}_{100} \mathrm{R}_{80}$ and in the greenhouse, although the average DLI in the greenhouse was $24 \%$ to $53 \%$ higher than that in the growth room. Confounding factors in the greenhouse environment may include air movement, radiation quality, radiation intensity (the DLI and fluctuating radiation throughout the day), photoperiod, photoinhibition under high radiation, vapor pressure deficit, and the growing method (hydroponics vs. soilless substrate). These uncontrolled variables should be considered when comparing results of the greenhouse and the growth room.

Anthocyanin accumulation was low in foliage without direct exposure to radiation due to shading from other leaves. The inclusion of $\mathrm{B}$ radiation at $20 \mu \mathrm{mol} \cdot \mathrm{m}^{-2} \cdot \mathrm{s}^{-1}$ was generally sufficient to saturate top foliage coloration and, thus, anthocyanin accumulation of 'Rouxai' lettuce, whereas $G$ radiation did not influence foliage coloration at a fixed B PFD. Similarly, the anthocyanin concentration of 'Red Cross' red-leaf lettuce was increased by substituting $130 \mu \mathrm{mol} \cdot \mathrm{m}^{-2} \cdot \mathrm{s}^{-1}$ of B radiation, but not $\mathrm{G}$ radiation, for white radiation at $300 \mu \mathrm{mol} \cdot \mathrm{m}^{-2} \cdot \mathrm{s}^{-1}(\mathrm{Li}$ and Kubota, 2009). Compared with $\mathrm{R}$ radiation, $\mathrm{B}$ radiation or $\mathrm{B}+\mathrm{R}$ radiation at $100 \mu \mathrm{mol} \cdot \mathrm{m}^{-2} \cdot \mathrm{s}^{-1}$ increased the anthocyanin concentration of 'Banchu Red Fire' red-leaf lettuce (Johkan et al., 2010). In addition, 2-h predawn applications of $B$ radiation at $45 \mu \mathrm{mol} \cdot \mathrm{m}^{-2} \cdot \mathrm{s}^{-1}$ increased anthocyanin concentrations in greenhouse-grown 'Lollo Rossa' red-leaf lettuce (Ouzounis et al., 2015). The observed anthocyanin accumulation under B radiation can be explained by the involvement of cryptochromes. In arabidopsis (Arabidopsis thaliana), cryptochrome 1 mediates anthocyanin accumulation under $\mathrm{B}$ radiation by upregulating flavonoid biosynthetic enzymes such as chalcone synthase (Bouly et al., 2007; Christie and Briggs, 2001; Jenkins et al., 1995). Cryptochrome 1 is also responsible for B radiationinduced anthocyanin accumulation in rapeseed (Brassica napus) (Chatterjee et al., 2006). Cryptochrome 2 can also regulate anthocyanin production under low $\mathrm{B}$ radiation, but not high $\mathrm{B}$ radiation, in which cryptochrome 2 undergoes rapid degradation (Christie and Briggs, 2001; Pedmale et al., 2016; Wang et al., 2001).

High light is an environmental stress that can elicit anthocyanin accumulation for protection against photodamage (Page et al., 2012). Acclimation to high light is accompanied by increases in flavonoid biosynthesis transcripts in arabidopsis (Page et al., 2012). Therefore, a high anthocyanin concentration in greenhouse-grown lettuce could be attributed to the high DLI. However, phytonutrients such as anthocyanins, phenolic secondary metabolites, and glucosinolates, which can accumulate under B radiation or high light, impart bitter and astringent tastes to fruits and vegetables while increasing the potential health benefits (Kopsell et al., 2015; Tomás-Barberán and Espín, 2001). Compared with lettuce grown under sole-source lighting, the lower ratings of greenhouse-grown lettuce for acceptability, flavor, aftertaste, and willingness to buy were associated with the higher ratings for bitterness. Consumers are generally averse to bitter plant foods regardless of their healthpromoting properties, which presents a dilemma for food producers (Drewnowski and Gomez-Carneros, 2000). However, bitter-tasting lettuce may be tolerable if mixed with other 
types of salad greens and dressings. In our study, lettuce grown under sole-source lighting had similar foliage coloration but lower bitterness ratings than the greenhouse counterpart, indicating similar anthocyanin accumulation but higher concentrations of other bitter compounds in the greenhouse-grown lettuce. Therefore, sole-source lighting can enable desirable coloration without negatively affecting sensory factors and consumer preferences. Although high $\mathrm{B}$ radiation slightly decreased the sweetness perception and texture likability, it did not influence the other sensory attributes.

Although substituting $G$ radiation for $R$ radiation did not affect macronutrient and micronutrient concentrations in 'Rouxai' lettuce, increasing B radiation increased concentrations of nitrogen, magnesium, sulfur, zinc, and copper. Similarly, substituting $10 \% \mathrm{G}$ radiation for $\mathrm{R}$ radiation did not affect macronutrient and micronutrient concentrations of broccoli (Brassica oleacea var. italica) microgreens at $5 \%$ or $20 \% \mathrm{~B}$ radiation, whereas increasing the $\mathrm{B}$ radiation fraction from $5 \%$ to $20 \%$ at a $P P F D$ of $250 \mu \mathrm{mol} \cdot \mathrm{m}^{-2} \cdot \mathrm{s}^{-1}$ increased concentrations of calcium, potassium, and sulfur (Kopsell et al., 2014). In addition, concentrations of macronutrients (phosphorus, potassium, magnesium, calcium, and sulfur) and micronutrients (boron, copper, iron, manganese, molybdenum, sodium, and zinc) in broccoli microgreens were higher under $\mathrm{B}_{41}$ than under $\mathrm{B}_{42} \mathrm{R}_{308}$ applied for $5 \mathrm{~d}$ before harvest (Kopsell and Sams, 2013). This suggests the accumulation of essential macronutrients and micronutrients is primarily mediated by relative $B$ radiation (its fraction of the $P P F D$ ) rather than absolute $\mathrm{B}$ radiation (its $P F D$ ). Promotion of nutrient uptake by $\mathrm{B}$ radiation is associated with increased stomatal opening, membrane permeability, proton extrusion, and ion transporters (Babourina et al., 2002; Kopsell et al., 2014; Spalding, 2000). Greenhousegrown lettuce had lower concentrations of potassium, manganese, and molybdenum and higher concentrations of magnesium and copper than lettuce grown under sole-source lighting. These differences could be attributed to different DLIs. For example, increasing the PPFD from 105 to $315 \mu \mathrm{mol} \cdot \mathrm{m}^{-2} \cdot \mathrm{s}^{-1}$ decreased concentrations of some macronutrients and micronutrients in some Brassica species and ornamental crops, but not others (Craver et al., 2018; Gerovac et al., 2016). Reduced nutrient concentrations under high light could be attributed to the dilution of nutrients at high shoot dry mass (Craver et al., 2018). However, greenhouse-grown lettuce in our study had both low concentrations of certain nutrients and low shoot dry mass; therefore, it had a low total content of those nutrients, which was possibly influenced by other environmental variables.

In conclusion, growth, morphology, and coloration of redleaf lettuce were primarily influenced by $B$ radiation with or without $\mathrm{G}$ radiation. Increasing the $\mathrm{B} P F D$ decreased shoot mass and leaf expansion but increased the red foliage coloration and concentrations of several macronutrients and micronutrients. Therefore, low B radiation promotes vegetative growth, whereas moderate-to-high $\mathrm{B}$ radiation enhances coloration and nutritional value. Temporally changing the spectrum can potentially optimize both yields and coloration. For example, a spectrum with a low ratio of $B$ to $R$ radiation could maximize yields during production, whereas a subsequent spectrum with a high ratio of $B$ to $R$ radiation 1 week before harvest could enhance red foliage coloration (Owen and Lopez, 2015). Interestingly, the role of $\mathrm{G}$ radiation in growth regulation depended on the B PFD. Although substituting $\mathrm{G}$ radiation for $\mathrm{R}$ radiation generally did not influence lettuce growth under little or no B radiation, it decreased the yield under moderate or high $B$ radiation. Sensory attributes and consumer preferences were generally unaffected by the quality of sole-source lighting but unfavorable for greenhouse-grown plants.

\section{Literature Cited}

Babourina, O., I. Newman, and S. Shabala. 2002. Blue light-induced kinetics of $\mathrm{H}^{+}$and $\mathrm{Ca}^{2+}$ fluxes in etiolated wild-type and phototropinmutant Arabidopsis seedlings. Proc. Natl. Acad. Sci. USA 99:24332438.

Bian, Z., Q. Yang, T. Li, R. Cheng, Y. Barnett, and C. Lu. 2018. Study of the beneficial effects of green light on lettuce grown under shortterm continuous red and blue light-emitting diodes. Physiol. Plant. 164:226-240.

Both, A.J., L.D. Albright, R.W. Langhans, R.A. Reiser, and B.G. Vinzant. 1997. Hydroponic lettuce production influenced by integrated supplemental light levels in a controlled environment agriculture facility: Experimental results. Acta Hort. 418:45-51.

Bouly, J.P., E. Schleicher, M. Dionisio-Sese, F. Vandenbussche, D. Van Der Straeten, N. Bakrim, S. Meier, A. Batschauer, P. Galland, R. Bittl, and M. Ahmad. 2007. Cryptochrome blue light photoreceptors are activated through interconversion of flavin redox states. J. Biol. Chem. 282:9383-9391.

Brodersen, C.R. and T.C. Vogelmann. 2010. Do changes in light direction affect absorption profiles in leaves? Funct. Plant Biol. 37:403-412.

Casal, J.J. 2000. Phytochromes, cryptochromes, phototropin: Photoreceptor interactions in plants. Photochem. Photobiol. 71:1-11.

Chatterjee, M., P. Sharma, and J.P. Khurana. 2006. Cryptochrome 1 from Brassica napus is up-regulated by blue light and controls hypocotyl/stem growth and anthocyanin accumulation. Plant Physiol. 141:61-74.

Christie, J.M. and W.R. Briggs. 2001. Blue light sensing in higher plants. J. Biol. Chem. 276:11457-11460.

Craver, J.K., J.K. Boldt, and R.G. Lopez. 2018. Radiation intensity and quality from sole-source light-emitting diodes affect seedling quality and subsequent flowering of long-day bedding plant species. HortScience 53:1407-1415.

Djakovic-Petrovic, T., M. de Wit, L.A. Voesenek, and R. Pierik. 2007. DELLA protein function in growth responses to canopy signals. Plant J. 51:117-126.

Dougher, T.A. and B. Bugbee. 2001. Evidence for yellow light suppression of lettuce growth. Photochem. Photobiol. 73:208-212.

Dougher, T.A. and B. Bugbee. 2004. Long-term blue light effects on the histology of lettuce and soybean leaves and stems. J. Amer. Soc. Hort. Sci. 129:467-472.

Drewnowski, A. and C. Gomez-Carneros. 2000. Bitter taste, phytonutrients, and the consumer: A review. Amer. J. Clin. Nutr. 72:14241435.

Folta, K.M. and S.A. Maruhnich. 2007. Green light: A signal to slow down or stop. J. Expt. Bot. 58:3099-3111.

Franklin, K.A. 2008. Shade avoidance. New Phytol. 179:930-944.

Gerovac, J.R., J.K. Craver, J.K. Boldt, and R.G. Lopez. 2016. Light intensity and quality from sole-source light-emitting diodes impact growth, morphology, and nutrient content of Brassica microgreens. HortScience 51:497-503.

Heo, J.W., D.H. Kang, H.S. Bang, S.G. Hong, C.H. Chun, and K.K. Kang. 2012. Early growth, pigmentation, protein content, and phenylalanine ammonia-lyase activity of red curled lettuces grown under different lighting conditions. Korean J. Hort. Sci. Technol. 30:6-12.

Hernández, R. and C. Kubota. 2016. Physiological responses of cucumber seedlings under different blue and red photon flux ratios using LEDs. Environ. Expt. Bot. 121:66-74.

Hogewoning, S.W., E. Wientjes, P. Douwstra, G. Trouwborst, W. Van Ieperen, R. Croce, and J. Harbinson. 2012. Photosynthetic quantum 
yield dynamics: From photosystems to leaves. Plant Cell 24:19211935.

Jenkins, G.I., J.M. Christie, G. Fuglevand, J.C. Long, and J.A. Jackson. 1995. Plant responses to UV and blue light: Biochemical and genetic approaches. Plant Sci. 112:117-138.

Johkan, M., K. Shoji, F. Goto, S.N. Hashida, and T. Yoshihara. 2010. Blue light-emitting diode light irradiation of seedlings improves seedling quality and growth after transplanting in red leaf lettuce. HortScience 45:1809-1814.

Kang, W.H., J.S. Park, K.S. Park, and J.E. Son. 2016. Leaf photosynthetic rate, growth, and morphology of lettuce under different fractions of red, blue, and green light from light-emitting diodes (LEDs). Hort. Environ. Biotechnol. 57:573-579.

Keuskamp, D.H., R. Sasidharan, I. Vos, A.J. Peeters, L.A. Voesenek, and R. Pierik. 2011. Blue-light-mediated shade avoidance requires combined auxin and brassinosteroid action in Arabidopsis seedlings. Plant J. 67:208-217.

Kim, H.H., G.D. Goins, R.M. Wheeler, and J.C. Sager. 2004. Greenlight supplementation for enhanced lettuce growth under red-and blue-light-emitting diodes. HortScience 39:1617-1622.

Kitaya, Y., G. Niu, T. Kozai, and M. Ohashi. 1998. Photosynthetic photon flux, photoperiod, and $\mathrm{CO}_{2}$ concentration affect growth and morphology of lettuce plug transplants. HortScience 33:988-991.

Kopsell, D.A. and C.E. Sams. 2013. Increases in shoot tissue pigments, glucosinolates, and mineral elements in sprouting broccoli after exposure to short-duration blue light from light emitting diodes. J. Amer. Soc. Hort. Sci. 138:31-37.

Kopsell, D.A., C.E. Sams, T.C. Barickman, and R.C. Morrow. 2014. Sprouting broccoli accumulate higher concentrations of nutritionally important metabolites under narrow-band light-emitting diode lighting. J. Amer. Soc. Hort. Sci. 139:469-477.

Kopsell, D.A., C.E. Sams, and R.C. Morrow. 2015. Blue wavelengths from LED lighting increase nutritionally important metabolites in specialty crops. HortScience 50:1285-1288.

Kozai, T., G. Niu, and M. Takagaki (eds.). 2015. Plant factory: An indoor vertical farming system for efficient quality food production. Academic Press, Waltham, MA.

Lambers, H., F.S. Chapin, and T.L. Pons. 2008. Plant physiological ecology. Springer, New York, NY.

Li, Q. and C. Kubota. 2009. Effects of supplemental light quality on growth and phytochemicals of baby leaf lettuce. Environ. Expt. Bot. 67:59-64.

Lin, C. 2000. Plant blue-light receptors. Trends Plant Sci. 5:337-342. Lin, K.H., M.Y. Huang, W.D. Huang, M.H. Hsu, Z.W. Yang, and C.M. Yang. 2013. The effects of red, blue, and white light-emitting diodes on the growth, development, and edible quality of hydroponically grown lettuce (Lactuca sativa L. var. capitata). Scientia Hort. 150:86-91.

Massa, G.D., H.H. Kim, R.M. Wheeler, and C.A. Mitchell. 2008. Plant productivity in response to LED lighting. HortScience 43:19511956.

McCree, K.J. 1972. The action spectrum, absorptance and quantum yield of photosynthesis in crop plants. Agr. Meteorol. 9:191-216.

Meng, Q., N. Kelly, and E.S. Runkle. 2019. Substituting green or farred radiation for blue radiation induces shade avoidance and promotes growth in lettuce and kale. Environ. Expt. Bot. 162:383-391.

Mickens, M.A., E.J. Skoog, L.E. Reese, P.L. Barnwell, L.E. Spencer, G.D. Massa, and R.M. Wheeler. 2018. A strategic approach for investigating light recipes for 'Outredgeous' red romaine lettuce using white and monochromatic LEDs. Life Sci. Space Res. 19:5362.

OSRAM Sylvania Inc. 2019. LED ColorCalculator. 18 Aug. 2019. $<$ https://www.osram.us/cb/tools-and-resources/applications/ledcolorcalculator/index.jsp $>$.

Ouzounis, T., B. Razi Parjikolaei, X. Fretté, E. Rosenqvist, and C.O. Ottosen. 2015. Predawn and high intensity application of supplemental blue light decreases the quantum yield of PSII and enhances the amount of phenolic acids, flavonoids, and pigments in Lactuca sativa. Front. Plant Sci. 6:19.

Owen, W.G. and R.G. Lopez. 2015. End-of-production supplemental lighting with red and blue light-emitting diodes (LEDs) influences red pigmentation of four lettuce varieties. HortScience 50:676-684.

Page, M., N. Sultana, K. Paszkiewicz, H. Florance, and N. Smirnoff. 2012. The influence of ascorbate on anthocyanin accumulation during high light acclimation in Arabidopsis thaliana: Further evidence for redox control of anthocyanin synthesis. Plant Cell Environ. 35:388-404.

Park, Y. and E.S. Runkle. 2017. Far-red radiation promotes growth of seedlings by increasing leaf expansion and whole-plant net assimilation. Environ. Expt. Bot. 136:41-49.

Pedmale, U.V., S.S.C. Huang, M. Zander, B.J. Cole, J. Hetzel, K. Ljung, P.A. Reis, P. Sridevi, K. Nito, J.R. Nery, and J.R. Ecker. 2016. Cryptochromes interact directly with PIFs to control plant growth in limiting blue light. Cell 164:233-245.

Pierik, R., G.C. Whitelam, L.A. Voesenek, H. De Kroon, and E.J. Visser. 2004. Canopy studies on ethylene-insensitive tobacco identify ethylene as a novel element in blue light and plant-plant signalling. Plant J. 38:310-319.

Pierik, R., T. Djakovic-Petrovic, D.H. Keuskamp, M. de Wit, and L.A. Voesenek. 2009. Auxin and ethylene regulate elongation responses to neighbor proximity signals independent of gibberellin and DELLA proteins in Arabidopsis. Plant Physiol. 149:1701-1712.

Sager, J.C., W.O. Smith, J.L. Edwards, and K.L. Cyr. 1988. Photosynthetic efficiency and phytochrome photoequilibria determination using spectral data. Trans. Amer. Soc. Agr. Eng. 31:1882-1889.

Sasidharan, R., C.C. Chinnappa, L.A. Voesenek, and R. Pierik. 2008. The regulation of cell wall extensibility during shade avoidance: A study using two contrasting ecotypes of Stellaria longipes. Plant Physiol. 148:1557-1569.

Smith, H.L., L. McAusland, and E.H. Murchie. 2017. Don't ignore the green light: Exploring diverse roles in plant processes. J. Expt. Bot. 68:2099-2110.

Smith, H. and G.C. Whitelam. 1997. The shade avoidance syndrome: Multiple responses mediated by multiple phytochromes. Plant Cell Environ. 20:840-844.

Snowden, M.C., K.R. Cope, and B. Bugbee. 2016. Sensitivity of seven diverse species to blue and green light: Interactions with photon flux. PLoS One 11(10):e0163121.

Son, K.H. and M.M. Oh. 2013. Leaf shape, growth, and antioxidant phenolic compounds of two lettuce cultivars grown under various combinations of blue and red light-emitting diodes. HortScience 48:988-995.

Son, K.H. and M.M. Oh. 2015. Growth, photosynthetic and antioxidant parameters of two lettuce cultivars as affected by red, green, and blue light-emitting diodes. Hort. Environ. Biotechnol. 56:639-653.

Spalding, E.P. 2000. Ion channels and the transduction of light signals. Plant Cell Environ. 23:665-674.

Szczygiel, E.J., J.B. Harte, G.M. Strasburg, and S. Cho. 2017. Consumer acceptance and aroma characterization of navy bean (Phaseolus vulgaris) powders prepared by extrusion and conventional processing methods. J. Sci. Food Agr. 97:4142-4150.

Terashima, I., T. Fujita, T. Inoue, W.S. Chow, and R. Oguchi. 2009. Green light drives leaf photosynthesis more efficiently than red light in strong white light: Revisiting the enigmatic question of why leaves are green. Plant Cell Physiol. 50:684-697.

Tomás-Barberán, F.A. and J.C. Espín. 2001. Phenolic compounds and related enzymes as determinants of quality in fruits and vegetables. J. Sci. Food Agr. 81:853-876.

Wang, Y. and K.M. Folta. 2013. Contributions of green light to plant growth and development. Amer. J. Bot. 100:70-78.

Wang, H., L.G. Ma, J.M. Li, H.Y. Zhao, and X.W. Deng. 2001. Direct interaction of Arabidopsis cryptochromes with COP1 in light control development. Science 294:154-158.

Wang, J., W. Lu, Y. Tong, and Q. Yang. 2016. Leaf morphology, photosynthetic performance, chlorophyll fluorescence, stomatal de- 
velopment of lettuce (Lactuca sativa L.) exposed to different ratios of red light to blue light. Front. Plant Sci. 7:250.

Went, F.W. 1957. The experimental control of plant growth. Chronica Botanica, Waltham, MA.

Wollaeger, H.M. and E.S. Runkle. 2014. Growth of impatiens, petunia, salvia, and tomato seedlings under blue, green, and red light-emitting diodes. HortScience 49:734-740.
Wollaeger, H.M. and E.S. Runkle. 2015. Growth and acclimation of impatiens, salvia, petunia, and tomato seedlings to blue and red light. HortScience 50:522-529.

Zhang, T. and K.M. Folta. 2012. Green light signaling and adaptive response. Plant Signal. Behav. 7:75-78.

Zhang, T., S.A. Maruhnich, and K.M. Folta. 2011. Green light induces shade avoidance symptoms. Plant Physiol. 157:1528-1536. 